\title{
Faunal trophic structure at hydrothermal vents on the southern Mohn's Ridge, Arctic Ocean
}

\author{
Andrew K. Sweetman ${ }^{1,2,7, *}$, Lisa A. Levin ${ }^{3}$, Hans T. Rapp ${ }^{2,4}$, \\ Christoffer Schander ${ }^{2,4,5,6, \mp}$ \\ ${ }^{1}$ Norwegian Institute for Water Research (NIVA), Thormøhlensgate 53 D, 5005 Bergen, Norway \\ ${ }^{2}$ Centre for Geobiology (SFF), University of Bergen, Allégaten 41, 5020 Bergen, Norway \\ ${ }^{3}$ Center for Marine Biodiversity and Conservation and Integrative Oceanography Division, \\ Scripps Institution of Oceanography, 9500 Gilman Drive, La Jolla, California 92093-0218, USA \\ ${ }^{4}$ Department of Biology, ${ }^{5}$ Bergen Museum, and ${ }^{6}$ Uni research, University of Bergen, 5020 Bergen, Norway \\ ${ }^{7}$ Present address: International Research Institute of Stavanger (IRIS), 4068 Stavanger, Norway
}

\begin{abstract}
We explore the trophic ecology of heterotrophic fauna associated with a high temperature (HT) vent, 2 low temperature vents, a 'near-HT vent' habitat and a non-vent site situated at upper bathyal depths on the southern Mohn's Ridge in the Arctic Ocean. Only a single taxon (the gastropod Pseudosetia griegi) was found at the high temperature vent habitat. Their mean $\delta^{13} \mathrm{C}$ values were significantly lighter than conspecifics from a low temperature vent habitat within the same vent field, reflecting the incorporation of sulfide oxidizing bacteria into the biomass of the animals. The majority of fauna from the low temperature, near-HT, and non-vent habitats had isotopic signatures indicative of assimilation of photosynthetic material. However, we found remarkably diverse isotopic compositions among the fauna sampled here, with a small sub-set of fauna at each site possessing $\mathrm{C}$ and $\mathrm{N}$ isotopic signatures indicative of incorporation of chemosynthetic production. Moreover, when isotopic signatures of similar taxa were compared from the same sample, $\delta^{13} \mathrm{C}$ signatures suggested a high degree of trophic complexity can exist over relatively small spatial scales at vent habitats on the southern Mohn's Ridge. The high contribution of photosynthetic food material to faunal diets and variability in food types may result from the upper bathyal venting depth and sedimentary nature of the vents. We hypothesize that the upper bathyal depth of active venting may lead to iron enhancement of surface photosynthetic production, especially in high nutrient areas, which ultimately sinks to the seabed where it is incorporated by fauna around the vents.
\end{abstract}

KEY WORDS: Hydrothermal vents $\cdot$ Fauna $\cdot$ Stable isotopes $\cdot$ Mixing models $\cdot$ Southern Mohn's Ridge

Resale or republication not permitted without written consent of the publisher

\section{INTRODUCTION}

Most deep-sea benthic communities rely on exported phytodetritus and its more labile components from the euphotic zone for food (Smith et al. 2008, 2009). At hydrothermal vent systems, however, chemosynthesis can play a large role in providing nutrients to deep-sea benthic communities (Rau \& Hedges 1979, Rau 1981, Van Dover 2000). Hydro- thermal vents occur along active mid-ocean ridges in all ocean basins, on a number of back-arc spreading centers and seamounts (Van Dover et al. 2000), and more recently were discovered at sites off-axis (Lizarralde et al. 2010) and on convergent margins (Ohara et al. 2012). Fluids that vent from these habitats are typically geothermally heated and enriched in energy-yielding reduced compounds such as sulfide and methane (e.g. Charlou et al. 2000, Van 
Dover 2000, Desbruyères et al. 2001). Micro-organisms can live symbiotically within faunal host tissues using vent-derived reduced compounds as chemical energy sources for organic carbon (C) production and providing a major source of energy to their hosts (Van Dover \& Fry 1989, Dubilier et al. 2008). Alternatively, chemosynthetic and heterotrophic bacteria growing on vent deposits or in the water column may be grazed upon by fauna or filtered from the water column by suspension-feeding invertebrates (Van Dover \& Fry 1994, Colaco et al. 2002a, Kongsrud \& Rapp 2012). Photosynthetic production may also provide food to fauna at hydrothermal vents (e.g. Dixon et al. 2006, Limén et al. 2007)

Until recently, most of the nutritional studies at deep-sea vents focused on the central and southern Mid Atlantic Ridge (MAR) (Colaco et al. 2002a,b, De Busserolles et al. 2009), the Galapagos Rift (Fisher et al. 1994), the Juan de Fuca Ridge (Van Dover \& Fry 1994, Limén et al. 2007, Levin et al. 2009), the East Pacific Rise (Rau 1981, Gaudron et al. 2012), the Guaymas Basin (Soto 2009) and ridge systems in the Western Pacific (e.g. Lau Basin, Manus Basin) (Erickson et al. 2009, Levin et al. 2009). In 2005, a suite of upper bathyal depth hydrothermal vents were discovered during the BIODEEP-05 cruise to the southern Mohn's Ridge (SMR) located on the Arctic MidOcean Ridge (AMOR), north of Jan Mayen (Pedersen et al. 2005, 2010a; see Fig. 1). Here, venting takes place within 2 main areas separated by $\sim 5 \mathrm{~km}$ (Pedersen et al. 2005, 2010a). The shallowest vent area is composed of 2 vent fields named Trollveggen and Gallionella Garden. These vent fields lie at water depths between 556 and $616 \mathrm{~m}$ (Pedersen et al. 2010a, Schander et al. 2010). The vent area stretches $\sim 1 \mathrm{~km}$ along the strike of a normal fault, and is composed of up to 20 vents discharging hot $\left(260^{\circ} \mathrm{C}\right)$ fluids. A large area of diffuse, low temperature (LT) venting $\left(\sim 7^{\circ} \mathrm{C}\right)$ surrounds the high temperature (HT) area (Pedersen et al. 2005, 2010a). The other vent area, named Soria Moria, is located on a rifted volcanic ridge and lies at a water depth of between 700 and $750 \mathrm{~m}$. Here, venting takes place at 2 fields, where white smoker fluids with temperatures of up to $270^{\circ} \mathrm{C}$ discharge from a variety of chimneys. The site is composed of $10 \mathrm{~m}$ tall, sulfate and sulfide formations that discharge lower temperature fluids (Pedersen et al. 2005, 2010a). To date, a total of 180 taxa have been identified from vent sites on the SMR (Schander et al. 2010). Surprisingly, the vent fauna at the SMR appears to be dominated by local bathyal species despite vent depths $>200 \mathrm{~m}$, where vent habitats typically shift from dominance by back- ground fauna to habitats composed largely of ventendemic organisms (Tarasov et al. 2005).

At the SMR there is a notable absence of ventendemic, symbiont-bearing fauna, typically found at Atlantic vents south of Iceland (Desbruyères et al. 2001, Schander et al. 2010). Rissoid gastropods occur in large abundance on bacterial mats that cover vent chimneys (see Fig. 2A,B) and completely dominate the fauna in these parts of the vent system (Schander et al. 2010). Large aggregations of mobile crinoids (e.g. Heliometra glacilis and Gorgonocephalus eucnemis) are also very common and occupy large areas around the vent fields (Schander et al. 2010). The recently discovered Loki's Castle vent field north of the SMR on the Knipovich Ridge provides evidence that Iceland creates a dispersal and migration barrier that isolates the Arctic from the MAR. Specifically, Loki's Castle vent fauna displays local adaptation, supporting both bacterial grazers and chemosynthetic symbionts (Pedersen et al. 2010b, Kongsrud \& Rapp 2012, Tandberg et al. 2012), with stronger affinities with their Pacific than Atlantic counterparts. Additional factors contributing to the lack of vent endemic taxa at the SMR may also include the cold surrounding water temperature $\left(-0.7^{\circ} \mathrm{C}\right)$ and shallow depth of the vents, which result in extensive competition with background fauna (Schander et al. 2010).

Limited sediment cover characterizes the substrate at most hydrothermal habitats studied on the central MAR and East Pacific Rise (EPR) (Van Dover 2000, Desbruyères et al. 2001, Van Dover et al. 2002). However, at other vent sites (e.g. in Guaymas Basin, Gulf of California and Loki Castle, Arctic Ocean) strong pelagic-benthic coupling can result in sedimentation of surface-derived organic matter or fine hydrothermal precipitates and a build-up of sediments around the vents (Vanreusel et al. 1997, Levin et al. 2009, Soto 2009). At vent sites on the SMR, hydrothermal fluids vent both from mineral- (e.g. anhydrite, barite, sphalerite, and pyrite) laden chimneys as well as through sediments at the seafloor (Pedersen et al. 2010a). Hydrothermal fluids venting through sediments may promote chemosynthetic microbial activity within the sediments, thereby enhancing food availability as well as increasing the diversity of nutritional sources (e.g. both photosynthetic and chemosynthetic-based) available to resident fauna (Levin et al. 2009). Fluids discharging from LT vents can contain lower concentrations of reduced chemical species (e.g. sulfide) than higher temperature vents, as a result of subsurface mineral precipitation (e.g. Charlou et al. 2000). Both LT $\left(7^{\circ} \mathrm{C}\right)$ as well as HT $\left(270^{\circ} \mathrm{C}\right)$ vents occur at the SMR (Pedersen et al. 
2010a, Schander et al. 2010), and the fluids that vent from these habitats contain low $(0-500 \mu \mathrm{M})$ and high (3-4 mM) concentrations of sulfide and other reduced compounds, respectively (I. Thorseth unpubl. data). Because reduced chemical species are vital for chemosynthesis, fauna inhabiting HT vent habitats on the SMR may be more likely to derive their nutrition from endosymbioses or by grazing on chemosynthetic bacteria than the fauna found at lower temperature vent habitats.

The establishment of stable isotope techniques in the late 1970's created numerous opportunities for study of faunal trophic interactions in shallow as well as deep-sea habitats, including hydrothermal vents (Conway et al. 1994, Fisher et al. 1994, Colaco et al. 2002a,b, Levin et al. 2009) and methane seeps (Levin \& Michener 2002, Levin \& Mendoza 2007, Bernardino \& Smith 2010, Demopoulos et al. 2010, Thurber et al. 2010). The diversity of metabolic/carbon fixation pathways adopted by vent microbes (Hügler \& Sievert 2011) generates distinctive $\delta^{13} \mathrm{C}$ signatures that provide good biomarkers of chemosynthesis. For example, C-fixation driven by energy derived from sulfide oxidation often results in relatively light $\delta^{13} \mathrm{C}$ values (e.g. down to $\sim-40 \%$ o) (Kennicutt et al. 1992), whereas $C$ fixed via the reverse tri-carboxylic acid (TCA) cycle imparts relatively heavy $\delta^{13} \mathrm{C}$ values (e.g. -15 to $-10 \%$ ) (Hügler \& Sievert 2011). Moreover, symbiotic or free-living chemoautotrophic microbes typically fix local nitrogen resulting in expression of light or negative $\delta^{15} \mathrm{~N}$ signatures in consumer tissues around chemosynthetic habitats (Paull et al. 1985, Kennicutt et al. 1992).

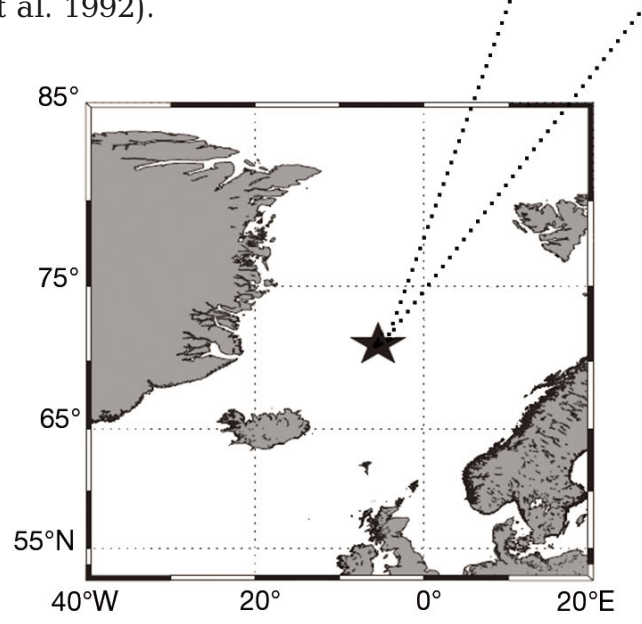

Fig. 1. (A) Location of the southern Mohn's Ridge (SMR) and (B) close-up of Trollveggen, Gallionella Garden, and Soria Moria hydrothermal vent sites in the Arctic Ocean
The primary aim of this investigation was to identify likely food sources and quantify the importance of chemosynthesis to faunal nutrition at hydrothermal habitats on the SMR. To do this, we compared naturally occurring $\mathrm{C}$ and $\mathrm{N}$ stable isotope signatures of fauna collected from areas near low $\left(\sim 7^{\circ} \mathrm{C}\right)$ and HT $\left(\sim 270^{\circ} \mathrm{C}\right)$ vents, and at sites without any detectable hydrothermal activity (hereafter termed 'non-vent').

\section{MATERIALS AND METHODS}

Microbes, epibiota, sediment infauna, zooplankton, phytoplankton, and suspended particulate organic matter (SPOM) were collected between the 21 to 26 July 2008 during RV 'G.O. Sars' cruise GS08-154 to 2 vent fields (Trollveggen and Gallionella Garden) located on the SMR (Fig. 1). Study sites within the Trollveggen vent field included an $\mathrm{HT}\left(270^{\circ} \mathrm{C}\right)$ vent habitat (Troll-HT; Fig. 2A,B); a site located $\sim 500 \mathrm{~m}$ away from the Troll-HT site (Troll-Near H or Troll-

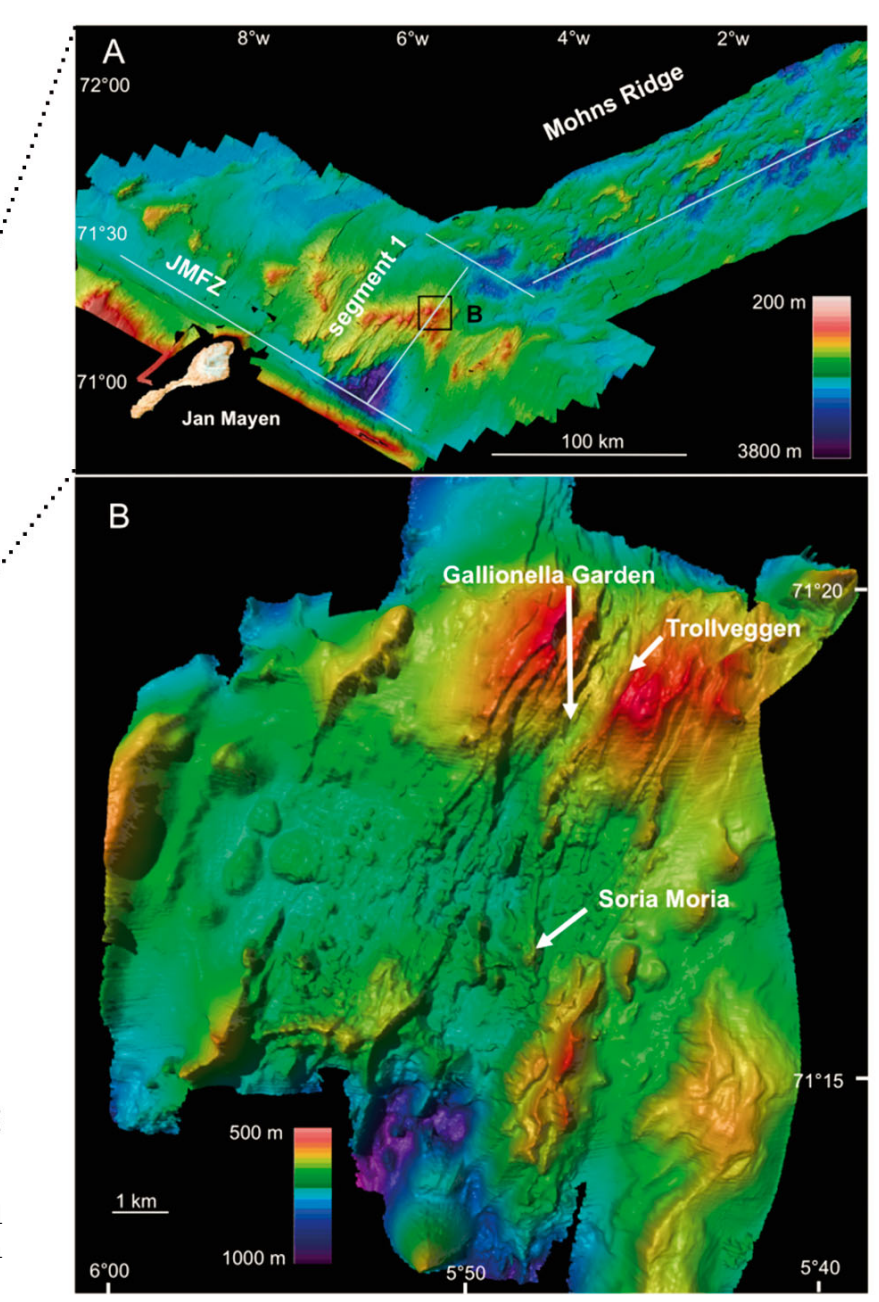



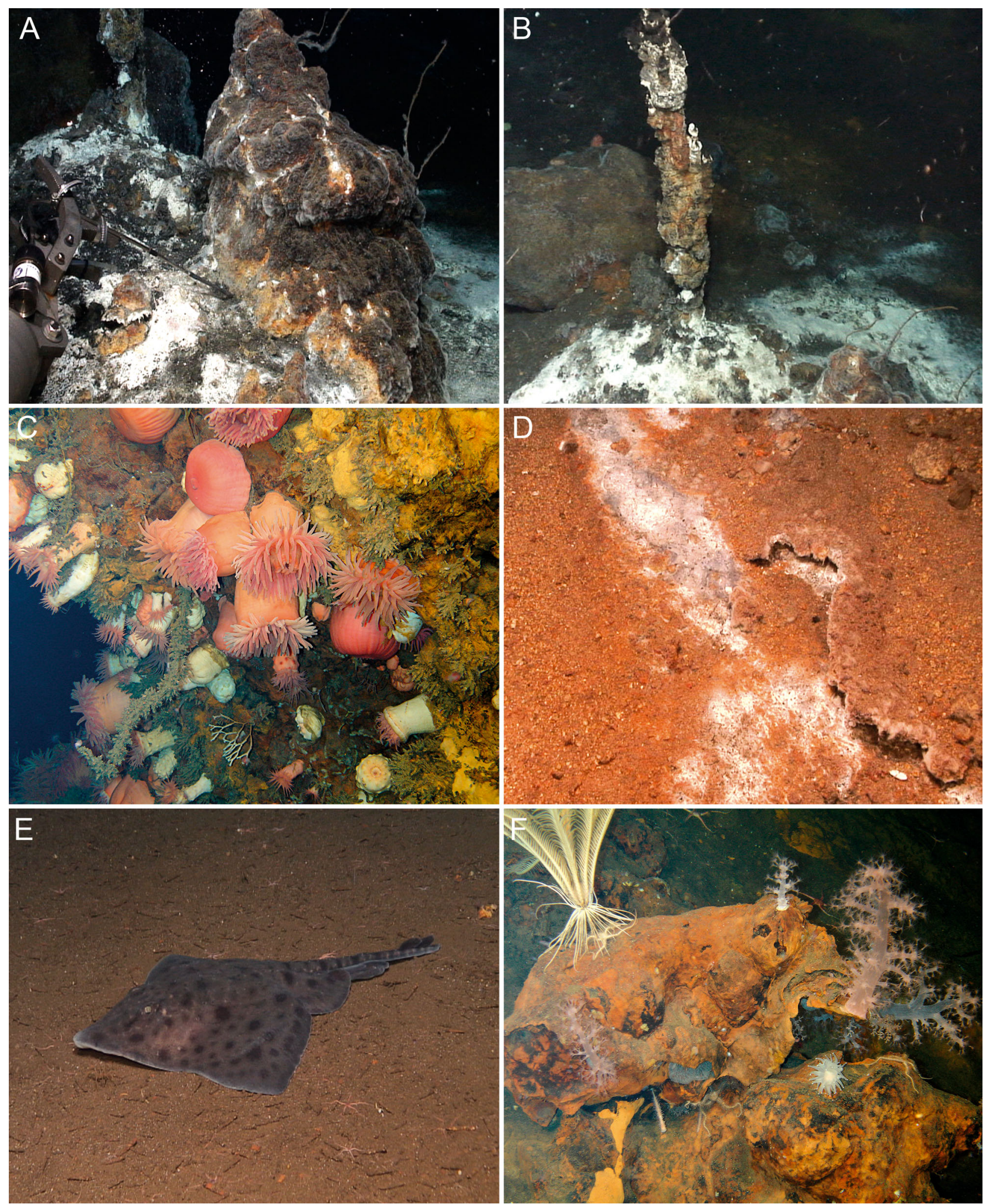

Fig. 2. Sampling locations at the southern Mohn's Ridge vent fields (for details of sites see Table 1). Trollveggen: (A,B) high temperature (HT) venting through active chimneys (Troll-HT), (C) low temperature (LT) venting, low-activity chimney structure with very rich epifauna (Troll-LT), (D) sediments with more diffuse LT venting (Troll-LT), and (E) no visible signs of hydrothermal activity (Troll-NHT). Gallionella Garden: (F) LT venting and iron deposits (Gall-LT) 
Table 1. Description of sampling stations. HT: high temperature vent; LT: low T vent; NHT: near HT vent; NV: non-vent

\begin{tabular}{|c|c|c|c|c|c|c|}
\hline Location & $\begin{array}{l}\text { Type of } \\
\text { sampling } \\
\text { site }\end{array}$ & $\begin{array}{l}\text { Depth } \\
\text { (m) }\end{array}$ & $\begin{array}{l}\text { ROV dive/ } \\
\text { Box-core }\end{array}$ & $\begin{array}{l}\text { Latitude } \\
\qquad\left({ }^{\circ} \mathrm{N}\right)\end{array}$ & $\begin{array}{l}\text { Longitude } \\
\quad\left({ }^{\circ} \mathrm{W}\right)\end{array}$ & Samples collected \\
\hline \multicolumn{7}{|l|}{ Seafloor samples } \\
\hline Trollveggen & HT & 556 & 8B-11-ROV3 & $71^{\circ} 17.52$ & $5^{\circ} 46.22$ & $\begin{array}{l}\text { Pseudosetia griegi recovered from the } \\
\text { surface of an osmosampler. Bacterial } \\
\text { mats (unidentified), sulfide oxidizing } \\
\text { bacterial mats and iron oxide samples } \\
\text { also recovered. }\end{array}$ \\
\hline Trollveggen & HT & 558 & 8B-44-ROV10 & $71^{\circ} 17.52$ & $5^{\circ} 46.22$ & $\begin{array}{l}\text { Bacterial mat (unidentified) sampled } \\
\text { from the surficial sediment by ROV }\end{array}$ \\
\hline Trollveggen & LT & 574 & 8B-43-ROV9 & $71^{\circ} 17.887$ & $5^{\circ} 46.386$ & $\begin{array}{l}\text { Fauna recovered from a ROV-operated } \\
\text { sediment scoop and by suction sampling }\end{array}$ \\
\hline Trollveggen & LT & 590 & 8B-35-BC5 & $71^{\circ} 17.939$ & $5^{\circ} 46.398$ & $\begin{array}{l}\text { Capitellid polychaete sampled from a ship- } \\
\text { deployed box-core }\end{array}$ \\
\hline Trollveggen & NHT & 524 & 8B-24-BC3 & $71^{\circ} 17.90$ & $5^{\circ} 46.36$ & $\begin{array}{l}\text { Fauna recovered from a ship-deployed } \\
\text { box-core }\end{array}$ \\
\hline Trollveggen & NHT & 560 & $8 B-27-B C 4$ & $71^{\circ} 17.90$ & $5^{\circ} 46.34$ & $\begin{array}{l}\text { Fauna recovered from a ship-deployed } \\
\text { box-core, sulfidic, hydrothermal sedi- } \\
\text { ments, filamentous sulfide oxidizers } \\
\text { present }\end{array}$ \\
\hline Gallionella Garden & n LT & $\sim 600$ & 8B-9-ROV1 & $71^{\circ} 17.99$ & $5^{\circ} 46.84$ & $\begin{array}{l}\text { Two Heliometra glacilis specimens and } \\
\text { ophiuroids recovered from the surface of } \\
\text { an incubator }\end{array}$ \\
\hline Gallionella Garden & n LT & 615 & 8B-10-ROV2 & $71^{\circ} 17.99$ & $5^{\circ} 46.84$ & $\begin{array}{l}\text { Fauna collected using an ROV-operated } \\
\text { sediment scoop }\end{array}$ \\
\hline Gallionella Garden & n $\quad$ LT & 615 & $8 B-9-B C 2$ & $71^{\circ} 18.085$ & $5^{\circ} 47.016$ & $\begin{array}{l}\text { Fauna (inc. foraminifera) were sampled } \\
\text { from a ship-deployed box-corer }\end{array}$ \\
\hline Gallionella Garden & n NV & 574 & $8 \mathrm{~B}-5-\mathrm{BC} 1$ & $71^{\circ} 17.443$ & $5^{\circ} 43.429$ & $\begin{array}{l}\text { Fauna (inc. foraminifera) were sampled } \\
\text { from a ship-deployed box-corer }\end{array}$ \\
\hline Soria Moira & HT & $\sim 720$ & 8B-29-ROV6 & $71^{\circ} 15.556$ & $5^{\circ} 48.892$ & $\begin{array}{l}\text { Bacterial mats (unidentified) and phyto- } \\
\text { detritus were sampled by ROV sediment } \\
\text { scoops }\end{array}$ \\
\hline \multicolumn{7}{|c|}{ Water column samples } \\
\hline Plankton tow & $\begin{array}{l}\text { Through } \\
\text { plankton } \\
\text { cloud }\end{array}$ & $0-350$ & 8B-8-PN1 & $71^{\circ} 17.857$ & $5^{\circ} 46.059$ & $\begin{array}{l}\text { Phytoplankton samples and } 2 \text { Calanus } \\
\text { finmarchicus samples were collected }\end{array}$ \\
\hline CTD cast & NV & 600 & 8B-3-CTD1 & $71^{\circ} 18.22$ & $5^{\circ} 46.25$ & Suspended POM samples were collected \\
\hline $\begin{array}{l}\text { CTD cast at } \\
\text { Trollveggen }\end{array}$ & $\begin{array}{l}\text { Over HT } \\
\text { vent }\end{array}$ & 600 & 8B-CTD 342 & $71^{\circ} 17.88$ & $5^{\circ} 46.30$ & Suspended POM samples were collected \\
\hline
\end{tabular}

NHT; Fig. 2E), but $<50 \mathrm{~m}$ from another HT vent; and an LT $\left(7^{\circ} \mathrm{C}\right.$ ) habitat (Troll-LT; Fig. 2C,D) situated $\sim 100 \mathrm{~m}$ from the Troll-NHT site and $1.2 \mathrm{~km}$ from the Troll-HT site. Bacterial mats (unidentified) and phytodetritus were also sampled at an HT vent site at Soria Moria during ROV dive 8B-29-ROV6 (Table 1).

In the Trollveggen field, using the ROV 'Bathysaurus' (Argus remote systems), Pseudosetia griegi (Gastropoda), bacterial mats (unidentified forms and sulfide oxidizing filaments) and iron oxide sediments were sampled at the Troll-HT site during ROV dive 8B-11-ROV3 (Table 1). Gastropods were sampled from the surface of a single osmo-sampler that had been placed $\sim 1$ yr earlier at the side of a vent discharging vent fluids between 260 and $270^{\circ} \mathrm{C}$, though the waters surrounding the osmosampler never exceeded a maximum of $\sim 20^{\circ} \mathrm{C}$ (I. Thorseth pers. comm.). This taxon alone was found and sampled at the Troll-HT site. Unidentified bacterial mats were recovered from the same $\mathrm{HT}$ vent site at Trollveggen during ROV dive 8B-44-ROV10 (Table 1). Fauna from the Troll-LT site were sampled by a ROV-operated sediment scoop or by suction sampling during a single dive (Dive 8B-43-ROV9) and by a single shipdeployed box-corer (Core 8B-35-BC5) (Table 1). However, only a single animal (a capitelled polychaete) was recovered and analyzed for isotopes from the boxcore sample. Two faunal samples were collected from the Troll-NHT site using a box-corer (Cores 8B-24-BC3 and 8B-27-BC4, Table 1). 
In the Gallionella Garden vent field, sediments were sampled for fauna from an area characterized by LT diffuse venting (Gall-LT; Fig. 2F) using a shipdeployed box-corer (Core 8B-9-BC2) as well as from ROV sediment scoops (Dive 8B-10-ROV2) (Table 1). Epifauna (crinoids and ophiuroids) were collected by ROV manipulators throughout dive 8B-9-ROV1 (Table 1) in the same collection area as the ROV sediment scoop sample. Fauna were also collected by ROV from the surface of an osmoregulator placed on the seafloor at the Gall-LT site. Sediments were sampled by a single ship-deployed box-corer (Core 8B-5$\mathrm{BC} 1)$ in an area without any detectable hydrothermal activity (i.e. via temperature anomalies, visible plumes, absence of bacterial mats, iron oxides, hydrothermal precipitates), which was located $\sim 2 \mathrm{~km}$ from the Gall-LT site (Table 1). This non-vent site was termed Gall-NV.

ROV sediment scoops collected $\sim 0.002 \mathrm{~m}^{2}$ of sediment down to 5-10 cm depth. The ship-deployed box-cores sampled $0.1 \mathrm{~m}^{2}$ of sediment down to $20 \mathrm{~cm}$ depth, but no deep-living fauna (i.e. $<10 \mathrm{~cm}$ ) were ever detected in any box-core samples. Sediments from Trollveggen were characterized by grey, black and white hydrothermal sediments, including sulfides and talc. Sedimentary texture was variable and included pebbles, rocks, as well as coarse sand. At Gallionella Garden, sediments contained hydrothermal crusts and bright orange flocculent material, along with some coarse sand.

Fauna were sieved from box-cored/ROV-scooped sediments in cool, filtered seawater using a $300 \mu \mathrm{m}$ mesh. Thus, our analysis includes some groups normally considered meiofauna, but their inclusion does not influence our comparison between isotope ratios of fauna from the different sites. Sieved fauna, microbial mats and filaments and phytodetritus samples were sorted and tentatively identified on board the ship under a dissecting microscope. Fauna were kept cool by refrigeration and allowed to evacuate their guts for $24 \mathrm{~h}$. Single reference animal samples were separated and preserved in buffered $4 \%$ formaldehyde seawater to enable subsequent species-level identification. Individual animals for isotopic analysis, microbes, phytodetritus and iron oxides were then rinsed in Milli-Q water and 0.2 to $1 \mathrm{mg}$ of material was placed in pre-weighed tin caps. Calcareous fauna were placed in pre-combusted $\left(500^{\circ} \mathrm{C}\right.$ for $6 \mathrm{~h}$ ) glass vials for subsequent processing. Tin caps and glass vial contents were oven-dried at $60^{\circ} \mathrm{C}$ overnight and shipped dry. Fauna in glass vials were then removed from shells and placed in tin caps. Contents of all caps were weighed, acidified with $1 \% \mathrm{PtCl}_{2}$ to remove inorganic carbon, and then dried at $60^{\circ} \mathrm{C}$ overnight. Samples were then stored dry in a dessicator until isotopic analysis.

We also collected additional food-source samples, including zooplankton, phytoplankton and suspended particulate organic matter (SPOM) (Table 1). Zooplankton samples were collected by towing a standard plankton net (500 $\mu \mathrm{m}$ mesh) at the sea surface in the general area of the vents. Calanus finmarchicus and phytoplankton were sampled between 0 and $350 \mathrm{~m}$ during a single plankton net (500 $\mu \mathrm{m}$ mesh) tow through a plankton cloud in the vicinity of the study area (Tow 8B-8-PN1, Table 1). At the surface, all zooplankton were manually separated from other debris and identified to coarse taxonomic resolution under a dissecting microscope. After sorting, all zooplankton samples were frozen at $-20^{\circ} \mathrm{C}$. SPOM was collected by a CTD rosette system at $600 \mathrm{~m}$ depth over a HT vent site at Trollveggen (Cast 8B-CTD342) and in a non-vent area (Cast 8B-3-CTD1) (Table 1). Once the CTD was back on deck, water samples (3 to 5 l) were immediately filtered on pre-combusted $\left(500^{\circ} \mathrm{C}, 6 \mathrm{~h}\right)$ glass-fiber (GF) filters and then frozen at $-20^{\circ} \mathrm{C}$. Back in the laboratory, frozen SPOM and zooplankton samples were processed as described above for benthic samples.

Sample (fauna and food-sources) $\delta^{13} \mathrm{C}$ and $\delta^{15} \mathrm{~N}$ signatures were measured using a Costech elemental analyzer interfaced with a continuous flow micromass Isoprime isotope ratio mass spectrometer (IRMS) at Washington State University. Sample C $\left({ }^{13} \mathrm{C} /{ }^{12} \mathrm{C}\right)$ and $\mathrm{N}\left({ }^{15} \mathrm{~N} /{ }^{14} \mathrm{~N}\right)$ isotopic ratios were expressed in delta $(\delta)$ notation (units of \%o) as relative difference between sample and standard: $\delta X(\%)=$ $\left[\left(R_{\text {sample }}\right) /\left(R_{\text {standard }}\right)-1\right] \times 10^{3}$, where $X$ denotes the heavy isotope (e.g. ${ }^{13} \mathrm{C}$ or ${ }^{15} \mathrm{~N}$ ) and $R$ the ratio between heavy and light isotopes (e.g. ${ }^{13} \mathrm{C} /{ }^{12} \mathrm{C}$ or $\left.{ }^{15} \mathrm{~N} /{ }^{14} \mathrm{~N}\right)$. Standards were Pee Dee Belemnite for $\delta^{13} \mathrm{C}$, and $\mathrm{N}_{2}$ gas (atmospheric) for $\delta^{15} \mathrm{~N}$.

The multi-source mixing model, Isosource (Phillips \& Gregg 2003), was used to estimate proportional contributions of 6 food sources to fauna sampled from the Troll-HT, Troll-LT, Troll-NHT, Gall-LT, and GallNV habitats. To use this model, we assumed all faunal $\delta^{13} \mathrm{C}$ and ${ }^{15} \mathrm{~N}$ signatures exhibited trophic fractionation, which was set at 1 and $3 \%$ for $\mathrm{C}$ and $\mathrm{N}$, respectively (Fry \& Sherr 1984, Minagawa \& Wada 1984). All corrected macrofaunal isotopic signatures were then plotted in $2 \mathrm{D}$ space $\left(\delta^{13} \mathrm{C} \times \delta^{15} \mathrm{~N}\right)$ (Fig. 3) along with the isotopic signatures of all the food types shown in Fig. 4. A polygon was then drawn narrowly around the individual macrofauna isotopic signatures (Fig. 3), with the apices of the polygon 


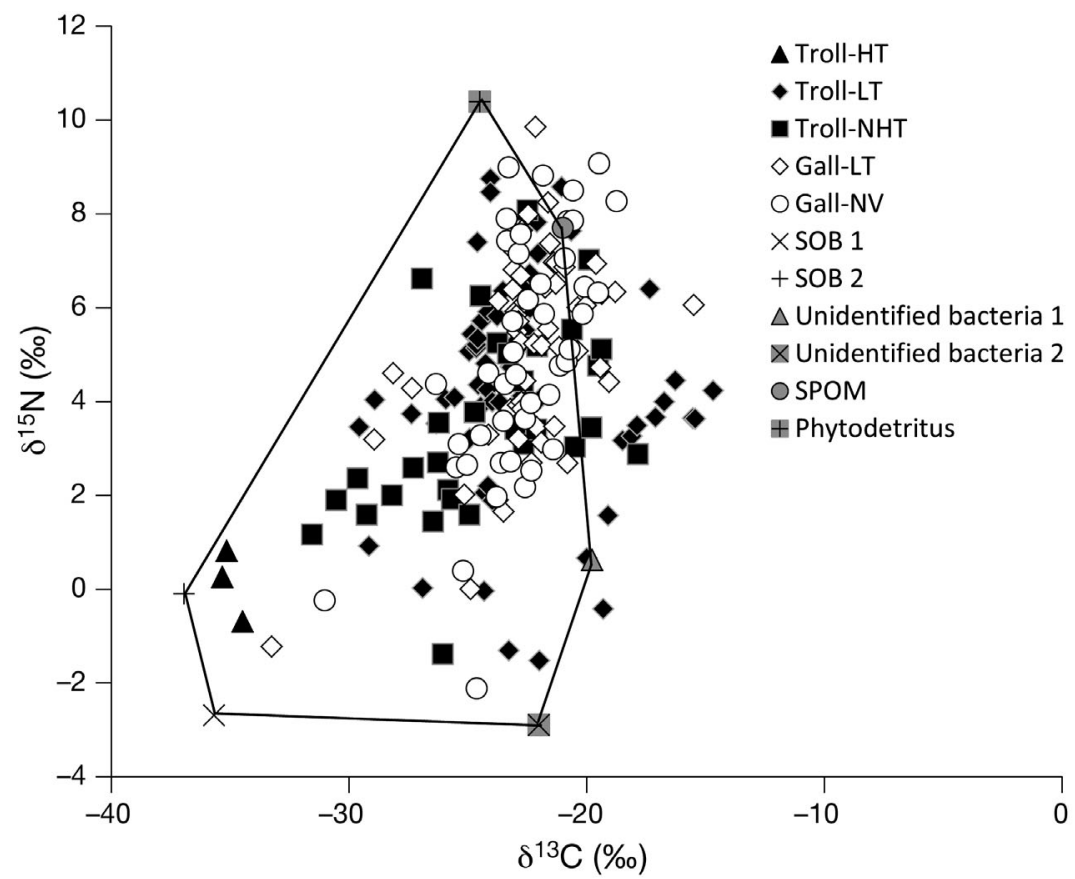

Fig. 3. Mixing polygon for isotope values of fauna and food sources used in the mixing model. Faunal isotope values that fell outside the polygon were not used in the mixing model. SOB: sulfide oxidizing bacteria, SPOM: suspended particulate organic matter. See 'Materials and methods' and Table 1 for site details

strained by the polygon. Source increments were set at $1 \%$ and tolerance at $0.086 \%$ for all mixing model calculations.

A variety of sampling methodologies were used to collect fauna at the 5 study sites, which can lead to collection of different fauna (i.e. a box-core samples deeper living fauna than a ROV scoop) and thus measurement of significantly different isotope signatures. However, $\delta^{13} \mathrm{C}$ signatures of fauna collected by ship-deployed boxcorers $(-22.0 \pm 0.3 \%$, $n=107)$ were not significantly different (MannWhitney $U$ test, $\mathrm{p}=0.346$ ) to pooled signatures of fauna collected using ROV sampling methods $(-22.2 \pm$ $0.4 \%, \mathrm{n}=88$ ). In terms of mean $\delta^{15} \mathrm{~N}$ signatures, no significant difference ( $t$-test, p $=0.270$ ) was detected between fauna collected using a boxcorer $(7.6 \pm 0.2 \%, \mathrm{n}=107)$ and those collected by ROV methods (7.3 \pm $0.2 \%$, $\mathrm{n}=88$ ). Because no significant artifacts were detected in the isotope data of samples collected using dif-

determined by single food-source isotope values that were closest to, and which best constrained the majority of the fauna isotopic signatures, as in UtnePalm et al. (2010) and Van der Bank et al. (2011) (Fig. 3). Average food-source isotope values were not used in the analysis. Food sources that did not constrain the data well (e.g. zooplankton, iron oxides, foraminifera, phytoplankton), and faunal isotopic signatures located outside of the mixing polygon ( 0 to $23 \%$ of the fauna isotope data sets from the 5 study sites) were not used in the analysis. The apices of the polygon were defined by 2 types of sulfide oxidizing bacteria (SOB) collected from the Troll-HT site (Dive 8B-11-ROV3; Table 1), 2 types of unidentified bacteria (from HT vent habitats at Trollveggen [Dive 8B44-ROV10] and Soria Moria [Dive 8B-29-ROV6]; Table 1), as well as apices representing SPOM collected at $600 \mathrm{~m}$ depth over a HT vent site at Trollveggen (Cast 8B-CTD 342; Table 1), and phytodetritus collected from the surface of seafloor sediments in a HT area at Soria Moria (Dive 8B-29-ROV6, Table 1). The isotopic signatures of these food types were then used as multiple end members in the Isosource mixing program (version 1.3.1; Phillips \& Gregg 2003) to calculate the minimum and maximum contribution from each food source with respect to all fauna conferent sampling methods, we pooled the ROV and box-core data sets for each site. Differences in faunal isotope signatures between sites were assessed using ANOVA or $t$-tests. Post-hoc comparisons for ANOVA were made using Tukey's HSD tests. If data sets failed to meet parametric assumptions (i.e. normality and homogeneity of variances), Kruskal-Wallis or Mann-Whitney tests were used and post-hoc comparisons for Kruskal-Wallis tests were carried out using Dunn's tests. An $\alpha$-level of 0.05 was chosen as the criterion for statistical significance. All data were analysed using Sigma-Stat (version 3.5, Systat) software. For the purposes of this paper, all data are expressed as means $\pm 1 \mathrm{SE}$, unless $\mathrm{n}=2$, where the error denotes the range.

\section{RESULTS}

\section{Food-source isotope signatures}

Stable $\mathrm{C}$ and $\mathrm{N}$ isotope signatures for all food sources sampled are shown in Fig. $4 . \delta^{13} \mathrm{C}$ signatures spanned a range of $17.2 \%$. SOB sampled at an HT vent site at Trollveggen (from Dive 8B-11-ROV3) had $\delta^{13} \mathrm{C}$ signatures of $-36.3 \pm 0.6 \%$ o $(\mathrm{n}=2)$, reflecting 


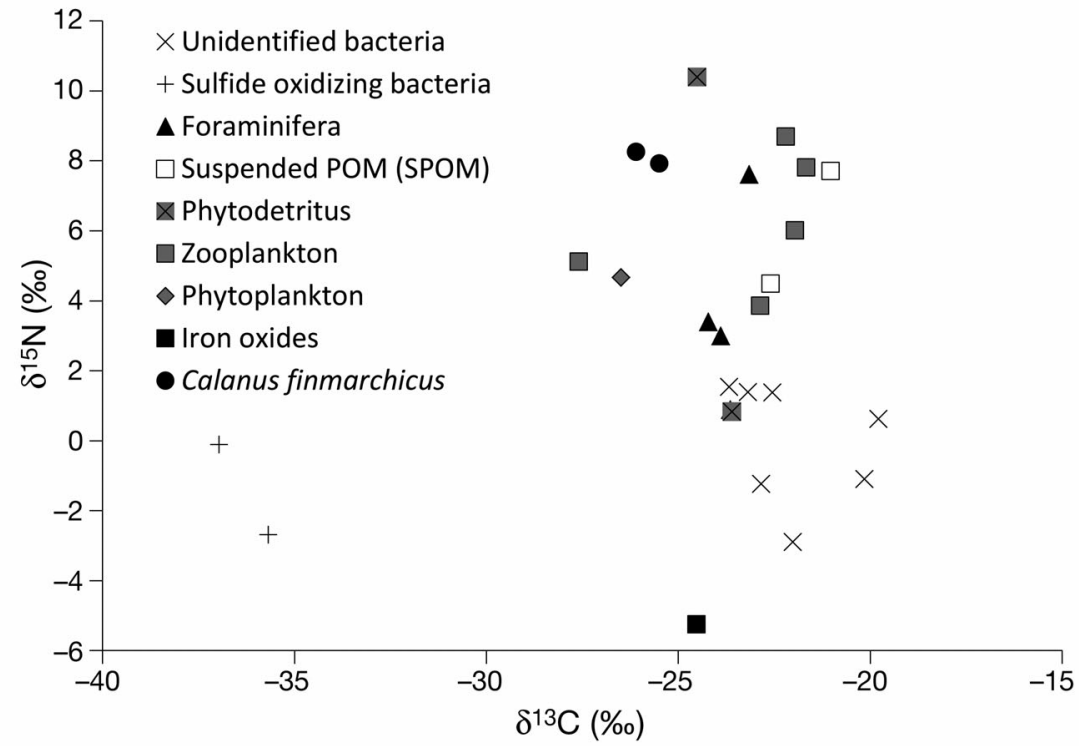

Fig. 4. Stable isotope signatures of potential faunal food sources collected at the seafloor or in the water column around the southern Mohn's Ridge vents

respectively ( $\mathrm{n}=3$; Fig. 5A). P. griegi were significantly more depleted in ${ }^{13} \mathrm{C}$ at the Troll-HT site (KruskalWallis, $\mathrm{p}=0.015)$ than conspecifics at the Troll-LT vent habitat $\left(\delta^{13} \mathrm{C}\right.$ $=-20.8 \pm 1.0 \%$, n $=5$; Fig. 5A,B). No significant difference was found in $P$. griegi $\delta^{13} \mathrm{C}$ signatures between the Troll-HT and Troll-NHT habitats $(-22.8 \pm 1.1 \%$, $\mathrm{n}=2)$, despite the large difference in mean $\delta^{13} \mathrm{C}$ signatures (Fig. 5A,C). Similarly, there was no difference in $\delta^{13} \mathrm{C}$ signatures of $P$. griegi from the Troll-NHT and LT sites (Fig. 5B,C).

Pseudosetia griegi $\delta^{15} \mathrm{~N}$ signatures were only significantly different (ANOVA, $\mathrm{p}=0.018$ ) amongst gastropods recovered from the Troll-LT $\left(\delta^{15} \mathrm{~N}=\right.$ $2.5 \pm 0.4 \%$, n $=5$; Fig. 5B) and TrollNHT habitats $(5.3 \pm 0.8 \%, \mathrm{n}=2$;

chemosynthetic carbon fixation. Signatures for photosynthesis-based food items (i.e. phytodetritus collected during Dive 8B-29-ROV6 and phytoplankton collected during Tow 8B-8-PN1) clustered around $-24.9 \pm 0.9 \%$ o $(\mathrm{n}=3)$. Unidentified bacterial samples collected from HT vent habitats at Trollveggen (Dives 8B-11-ROV3 and 8B-44-ROV10) and Soria Moria (Dive 8B-29-ROV6) possessed a mean $\delta^{13} \mathrm{C}$ signature of $-22.0 \pm 0.6 \%$ o $(n=7)$.

$\delta^{15} \mathrm{~N}$ values of food sources varied by $15.6 \%$. Photosynthesis-based food items averaged $5.3 \pm$ $2.8 \%$ o $(\mathrm{n}=3)$, with an average $\delta^{15} \mathrm{~N}$ signature $\sim 7 \%$ lighter $(-1.4 \pm 1.3 \%, \mathrm{n}=2)$ in SOB. The unidentified bacteria samples collected from sediments at HT vents at Soria Moria and Trollveggen also possessed very light, and sometimes negative $\delta^{15} \mathrm{~N}$ values $(0.0 \pm$ $0.6 \%$, n $=7$; Fig. 4) in a similar way to SOB from Trollveggen. This value reflects the fixation of local $\mathrm{N}$ by both SOB and unidentified bacteria. SPOM samples collected by CTD from $600 \mathrm{~m}$ depth had $\delta^{13} \mathrm{C}$ and $\delta^{15} \mathrm{~N}$ signatures of $-21.8 \pm 0.8 \%$ o $(\mathrm{n}=2)$ and $6.1 \pm$ $1.6 \%$ o $(\mathrm{n}=2)$, respectively, reflecting its photosynthetic origin.

\section{Isotopic signatures of specific taxa}

Pseudosetia griegi (Gastropoda). The only taxon observed and collected at the Troll-HT site was 3 specimens of the rissoid gastropod $P$. griegi. $\delta^{13} \mathrm{C}$ and $\delta^{15} \mathrm{~N}$ signatures of these gastropods from the Troll-HT site averaged $-34.0 \pm 0.3 \%$ and $3.1 \pm 0.4 \%$,
Fig. 5C). Overall, $\delta^{13} \mathrm{C}$ signatures of $P$. griegi spanned a range of $0.8,5.0$ and $2.3 \%$, at the Troll-HT, LT and NHT sites, respectively (see Table S1 in the supplement at: www.int-res.com/articles/suppl/m473p115_ supp.pdf; Fig. 5A-C). The close agreement between the $P$. griegi $\delta^{13} \mathrm{C}$ and $\delta^{15} \mathrm{~N}$ signatures (after correcting for fractionation) (Fig. 5A, Table S1) and the very depleted sulfide oxidizing bacteria isotope signatures at the Troll-HT site (Fig. 4) suggests that the gastropods fed on a narrow diet of SOB at the TrollHT site. The P. griegi from the Troll-NHT and TrollLT sites apparently fed on unidentified bacteria, as suggested by similar agreement between $\delta^{13} \mathrm{C}$ signatures of gastropods and unidentified bacteria collected from Trollveggen, which possessed $\delta^{13} \mathrm{C}$ and $\delta^{15} \mathrm{~N}$ signatures of $-22.7 \pm 0.5 \%(\mathrm{n}=3)$ and $0.0 \pm$ $1.5 \%$ o $(n=3)$, respectively (Figs. 4 \& 5B,C).

Capitellidae (Polychaeta). Capitellid polychaete $\delta^{13} \mathrm{C}$ values spanned a range of 5.2 and $9.1 \%$ at the Troll-LT and Troll-NHT sites, respectively (Fig. 5B,C, Table S1). At the Troll-LT site, capitellids exhibited 8 of the 10 heaviest $\delta^{13} \mathrm{C}$ signatures (mean signature for capitellids: $-16.4 \pm 0.5 \%, \mathrm{n}=9$; Fig. $5 \mathrm{~B}$ ) and 2 of the 4 heaviest $\delta^{13} \mathrm{C}$ signatures at the Troll-NHT habitat $(-20.8 \pm 2.0 \%$ o, $\mathrm{n}=4$; Fig. $5 \mathrm{C})$ (Table S1). $\delta^{13} \mathrm{C}$ signatures of capitellid polychaetes were significantly different between the Troll-LT and Troll-NHT sites $(t$-test, $\mathrm{p}=0.012)$. However, in terms of $\delta^{15} \mathrm{~N}$ values, no significant difference was detected (Mann-Whitney $U$ test, $\mathrm{p}=0.939$ ) between capitellids collected from the Troll-LT (7.1 $\pm 0.5 \%$ o, $\mathrm{n}=9$; Fig. 5B) and Troll-NHT sites (7.3 $\pm 0.8 \%$, $n=9$; Fig. 5C) (Table S1). 

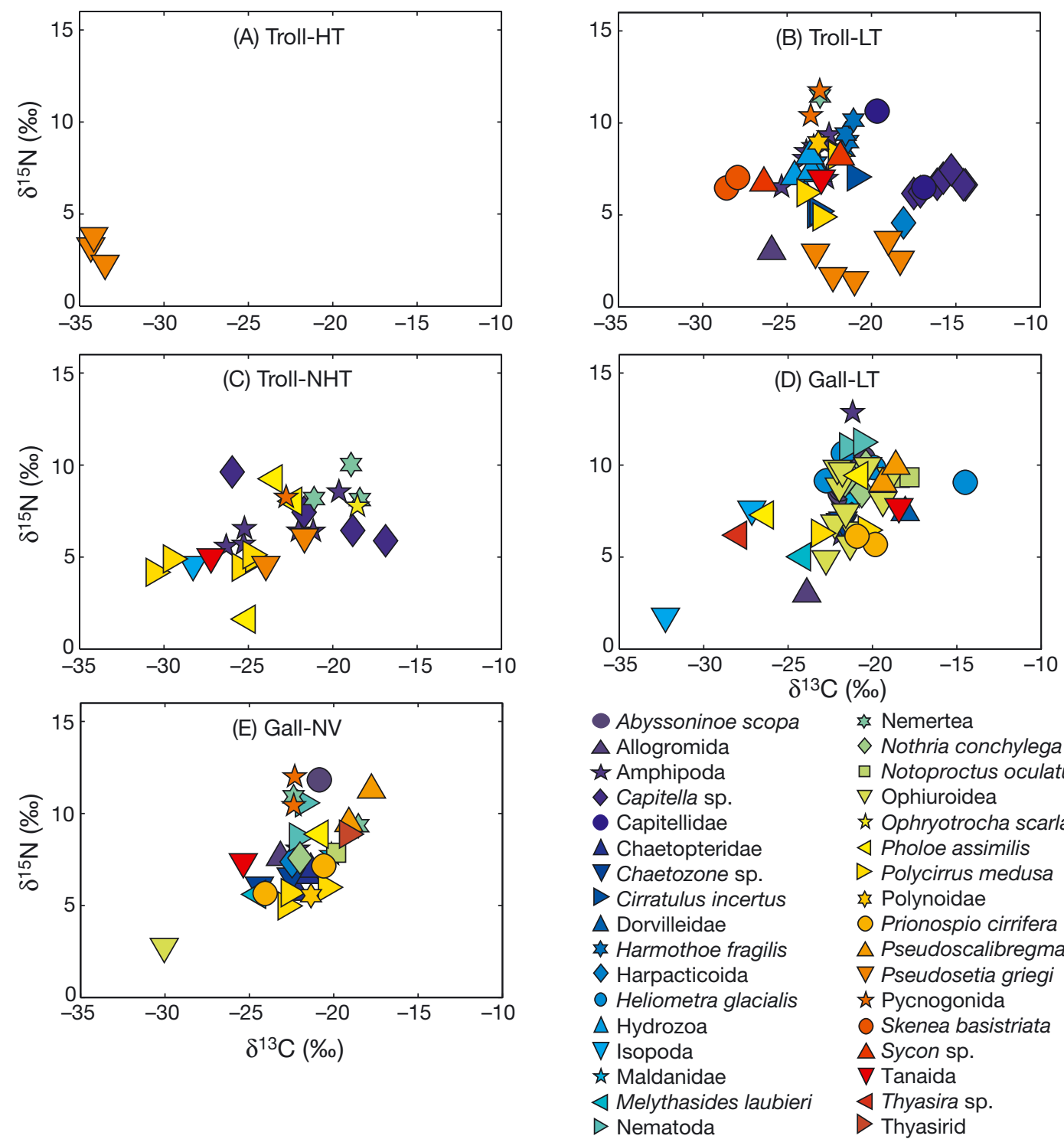

is Nemertea

$\diamond$ Nothria conchylega

$\square$ Notoproctus oculatus arctica

$\nabla$ Ophiuroidea

t. Ophryotrocha scarlatoi

$\triangleleft$ Pholoe assimilis

$\triangleright$ Polycirrus medusa

is Polynoidae

Prionospio cirrifera

$\triangle$ Pseudoscalibregma parvus

$\nabla$ Pseudosetia griegi

厺 Pycnogonida

- Skenea basistriata

$\triangle$ Sycon sp.

$\nabla$ Tanaida

$\checkmark$ Thyasira sp.

$\triangleright$ Thyasirid

Fig. 5. Stable isotope signatures of specific taxa sampled for isotopes from each of the 5 sites at (A-C) Trollveggen (Troll) and (D-E) Gallionella Garden (Gall) at the southern Mohn's Ridge. HT: high temperature vent; LT: low temperature vent; NHT: near HT vent; NV: non-vent

Amphipoda. $\delta^{13} \mathrm{C}$ values for amphipods ranged from $0.7,2.8$ and $6.7 \%$ at the Gall-LT, Troll-LT and Troll-NHT sites, respectively (Fig. 5B-D, Table S1). However, no significant difference was detected in $\delta^{13} \mathrm{C}$ values between the Gall-LT $(-21.5 \pm 0.4 \%$, $\mathrm{n}=2$ : Fig. 5D), Troll-LT ( $-23.5 \pm 0.3 \%, \mathrm{n}=9$ : Fig. 5B), and Troll-NHT (-23.3 $\pm 1.1 \%$, $\mathrm{n}=6$; Fig. $5 \mathrm{C})$ (Table S1) sites (ANOVA, $\mathrm{p}=0.235$ ). Average $\delta^{15} \mathrm{~N}$ values for amphipods at the Gall-LT, Troll-LT and Troll-NHT sites were $9.5 \pm 3.3 \%$ o $(\mathrm{n}=2$; Fig. $5 \mathrm{D}), 8.2 \pm 0.3 \%$ o $(\mathrm{n}=$ 9; Fig. 5B), and $6.5 \pm 0.4 \%$ ( $\mathrm{n}=6$; Fig. 5C) (Table S1), respectively, but no significant difference was detected between study sites (ANOVA, $p=0.083$ ).
Polycirrus medusa (Terebellidae, Polychaeta). $\delta^{13} \mathrm{C}$ ranged from 2.8, 2.4, 1.9, and 5.9\% at the Gall-LT, Gall-NV, Troll-LT and Troll-NHT sites, respectively (Fig. 5B-E). Mean $\delta^{13} \mathrm{C}$ values were significantly different (ANOVA, $p=0.023$ ) between the sites, with significantly different signatures only being found between the Gall-NV $(-22.0 \pm 0.8 \%$, $\mathrm{n}=3$; Fig. 5E) versus the Troll-NHT site $(-27.0 \pm 1.3 \%$, $\mathrm{n}=5$; Fig. $5 \mathrm{C})$ (Table S1). Average $\delta^{13} \mathrm{C}$ values were $-21.7 \pm 1.4 \%$ (n $=2)$ and $-23.0 \pm 0.5 \%(n=3)$ for the Gall-LT (Fig. 5D) and Troll-LT sites (Fig. 5B) (Table S1), respectively. Despite a lower average $\delta^{15} \mathrm{~N}$ value for $P$. medusa at the Troll-NHT site $(4.7 \pm 0.2 \%, \mathrm{n}=5$; Fig. $5 \mathrm{C})$, no signi- 
ficant difference was detected (Kruskal-Wallis, $\mathrm{p}=$ 0.083) between the Gall-LT $(6.4 \pm 0.1 \%$, $\mathrm{n}=2$; Fig. 5D), Gall-NV (5.6 $\pm 0.3 \%, \mathrm{n}=3$; Fig. 5E), Troll-LT $(6.4 \pm 1.0 \%$, n $=3$; Fig. $5 \mathrm{~B})$ (Table S1), or Troll-NHT sites.

\section{Comparison of faunal isotopic signatures across study sites}

Overall, $\delta^{13} \mathrm{C}$ signatures for all fauna spanned a range of $0.8,14.9,13.7,17.8$ and $12.3 \%$ at the Troll-HT, -LT, -NHT, Gall-LT and -NV sites, respectively (Table S1). Therefore, in contrast to the TrollHT site, a greater variety of food types appeared to support the fauna collected at the Troll-LT, TrollNHT, Gall-LT and Gall-NV sites. The maximum range in faunal $\delta^{13} \mathrm{C}$ signatures calculated from fauna collected in the same sample (ROV or shipdeployed sampling methods) was $0.8,14.9,12.2$, 13.8 and $12.3 \%$ for the Troll-HT, -LT, -NHT, GallLT and -NV sites, respectively. When closely related taxa were compared from a single sample collection, $\delta^{13} \mathrm{C}$ signatures for fauna ranged from $0.8 \%$ (Troll-HT), 12.2\%o (Troll-LT), 5.2\%o (Troll-NHT), 7.2\% (Gall-LT) and 3.8\% (Gall-NV). These results collectively point to wide differences in food sources amongst the different fauna over relatively small spatial scales within each site. Ranges in $\delta^{15} \mathrm{~N}$ were $1.5,10.3,9.5,11.1$ and $11.2 \%$ o the Troll-HT, -LT, -NHT, Gall-LT and -NV sites, respectively (Table S1) indicating $>1$ trophic level at all sites, except Troll-HT. However, only one habitat at the HT site was explored so multiple trophic levels cannot be ruled out at this and other HT sites.

On average, fauna collected from the different study sites displayed significantly different $\delta^{13} \mathrm{C}$ signatures (Fig. 6) when comparisons were made across study sites (Kruskal-Wallis, $\mathrm{p}<0.001$ ). At the Gall-LT site, $\delta^{13} \mathrm{C}$ signatures of all fauna $(-21.4 \pm 0.4 \%$, $\mathrm{n}=$ 55) were significantly heavier than those at the TrollHT $(-34.0 \pm 0.3 \%, \mathrm{n}=3)$ and Troll-NHT sites $(-23.3 \pm$ $0.6 \%, \mathrm{n}=31$ ) (Fig. 6). Faunal $\delta^{13} \mathrm{C}$ signatures were also significantly heavier at the Gall-NV site $(-21.7 \pm$ $0.3 \%, \mathrm{n}=44$ ) compared to signatures at the Troll-HT site (Fig. 6). No significant differences were found when pairwise comparisons were carried out on other groupings. Surprisingly, despite much lighter $\delta^{13} \mathrm{C}$ signatures at the Troll-HT site compared to the Troll-LT $(-21.7 \pm 0.4 \%, \mathrm{n}=62)$ and Troll-NHT sites (Fig. 6), no significant difference was detected between these sites. This is most likely the result of the small number of fauna collected at the Troll-HT site

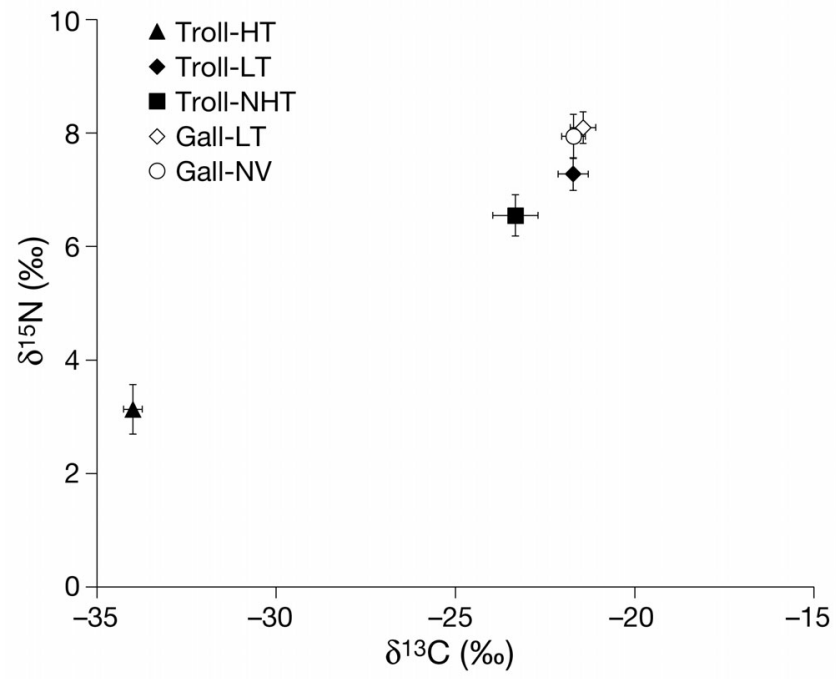

Fig. 6. Mean stable isotope signatures $( \pm 1 \mathrm{SE}$ ) of fauna collected from all 5 sites at Trollveggen (Troll) and Gallionella Garden (Gall) at the southern Mohn's Ridge. HT: high temperature vent; LT: low temperature vent; NHT: near HT vent; NV: non-vent

from a single microhabitat and the resulting low statistical power of the test. Faunal $\delta^{15} \mathrm{~N}$ signatures were significantly different across all 5 study sites (Kruskal-Wallis, $\mathrm{p}<0.001$ ), with significantly higher $\delta^{15} \mathrm{~N}$ values in fauna at the Gall-LT site $(8.1 \pm 0.3 \%, \mathrm{n}=55)$ compared to the Troll-HT (3.1 $\pm 0.4 \%, \mathrm{n}=3)$ and NHT sites (6.5 $\pm 0.4 \%$, $\mathrm{n}=31$ ) (Fig. 6). Signatures at the Gall-NV site $(7.9 \pm 0.4 \%$, $\mathrm{n}=44)$ were also significantly higher than those at the Troll-HT site (Fig. 6). Mean $\delta^{15} \mathrm{~N}$ signatures at the Troll-LT site were $7.3 \pm$ $0.3 \%$ o $(n=62)$ (Fig. 6).

Multiple taxa from both the Troll-LT and TrollNHT locations possessed very light $\delta^{13} \mathrm{C}$ (i.e. $<-26 \%$ ) and/or $\delta^{15} \mathrm{~N}$ signatures (i.e. $<4 \%$; Fig. 5B,C, Table S1). At the Troll-LT habitat, these taxa included 2 Skenea basistriata gastropods $\delta^{13} \mathrm{C}:-28.6$ and $-27.9 \%$; Fig. 5B), an unidentified polychaete $\left(\delta^{13} \mathrm{C}:-28.2 \%\right.$; $\left.\delta^{15} \mathrm{~N}: 3.9 \%\right)$, a Sycon sp. specimen $\left(\delta^{13} \mathrm{C}:-26.4 \%\right.$; Fig. 5B), 5 Pseudosetia griegi specimens (Fig. 5B) and an allogromid foraminiferan $\left(\delta^{15} \mathrm{~N}\right.$ : $3.0 \%$; Fig. $\left.5 \mathrm{~B}\right)$ (Table S1). From the TrollNHT locality they included 2 Polycirrus medusa specimens ( $\delta^{13} \mathrm{C}$ : -30.6 and $-29.6 \%$; Fig. 5C), an Amphitritinae polychaete $\left(\delta^{13} \mathrm{C}:-28.7 \%\right.$ ), a Pholoe assimilis $\left(\delta^{15} \mathrm{~N}\right.$ : $1.6 \%$; Fig. 5C) and Capitella sp. polychaete $\left(\delta^{13} \mathrm{C}:-26.0 \%\right.$, Fig. $\left.5 \mathrm{C}\right)$, an isopod $\left(\delta^{13} \mathrm{C}:-28.3 \%\right.$; Fig. $\left.5 \mathrm{C}\right)$, a tanaid $\left(\delta^{13} \mathrm{C}:-27.2 \%\right.$; Fig. 5C), and an amphipod $\left(\delta^{13} \mathrm{C}:-26.3 \%\right.$; Fig. $\left.5 \mathrm{C}\right)$ (Table S1). Multiple taxa from the Gall-LT and GallNV sites also exhibited light $\delta^{13} \mathrm{C}$ and/or $\delta^{15} \mathrm{~N}$ signatures (Table S1) including 2 isopods (Isopod $1=$ 
$\delta^{13} \mathrm{C}:-32.3 \%, \delta^{15} \mathrm{~N}$ : $1.8 \%$; Isopod $2=\delta^{13} \mathrm{C}:-27.1 \%$; Fig. 5D), a $P$. assimilis individual $\left(\delta^{13} \mathrm{C}\right.$ : $-26.3 \%$; Fig. 5D), a thyasirid bivalve $\left(\delta^{13} \mathrm{C}:-27.9 \%\right.$; Fig. 5D), and an allogromid foraminiferan $\left(\delta^{15} \mathrm{~N}: 3.0 \%\right.$; Fig. 5D) at Gall-LT, and 2 unidentified foraminifera $\left(\delta^{15} \mathrm{~N}: 3.4\right.$ and $0.9 \%$ ) at Gall-NV (Table S1). An ophiuroid possessed the most depleted $\delta^{13} \mathrm{C}$ value $(-30.0 \%)$ and a very light $\delta^{15} \mathrm{~N}$ signature $(2.8 \%)$ at Gall-NV (Fig. 5E, Table S1).

\section{Diet contributions based on mixing model results}

On average, SOB contributed most to the diets of Pseudosetia griegi at the Troll-HT site (a minimum of 0 and $47 \%$ and a maximum of 41 and $87 \%$ for SOB 1 and 2, respectively; Fig. 7, see Table S2 in the supplement at www.int-res.com/articles/suppl/ m473p115_supp.pdf), where percentage values are means calculated from the mixing model outputs for a particular food type for each organism. Maximum dietary contributions from SOB 2 to fauna were significantly greater $(\mathrm{p}<0.05)$ at the Troll-HT site com- pared to all other sites (Fig. 7B). Other food types contributed an average of between 0 and $12 \%$ to faunal diets at the Troll-HT site (Fig. 7). The maximum contribution of Unidentified bacteria 1, phytodetritus and SPOM to faunal diets was significantly lower at the Troll-HT site compared to all other sites sampled (Fig. 7B). SOB contributed 0 to 31 and 0 to $28 \%$ to $P$. griegi diets at the Troll-NHT and Troll-LT sites, respectively, whereas Unidentified bacteria 1 and 2 contributed 0 to $64 \%$ at the Troll-NHT site and 0 to $99 \%$ at the Troll-LT site (Table S2). Mean contributions of the various food sources to faunal diets were similar at the Troll-LT, Troll-NHT, Gall-LT and Gall-NV habitats (Fig. 7), which implied uniformity in diets among the fauna analyzed in the mixing model.

SPOM made up the largest dietary fraction in fauna at the Troll-LT, Troll-NHT, Gall-LT and GallNV sites (2 to $69 \%$; Fig. 7, Table S2), and the maximum contribution of SPOM to faunal diets was significantly higher than any other food source at the Troll-LT, Gall-LT and Gall-NV sites (Fig. 7B). However, the contribution of SOB to diets was $\geq 50 \%$ in a
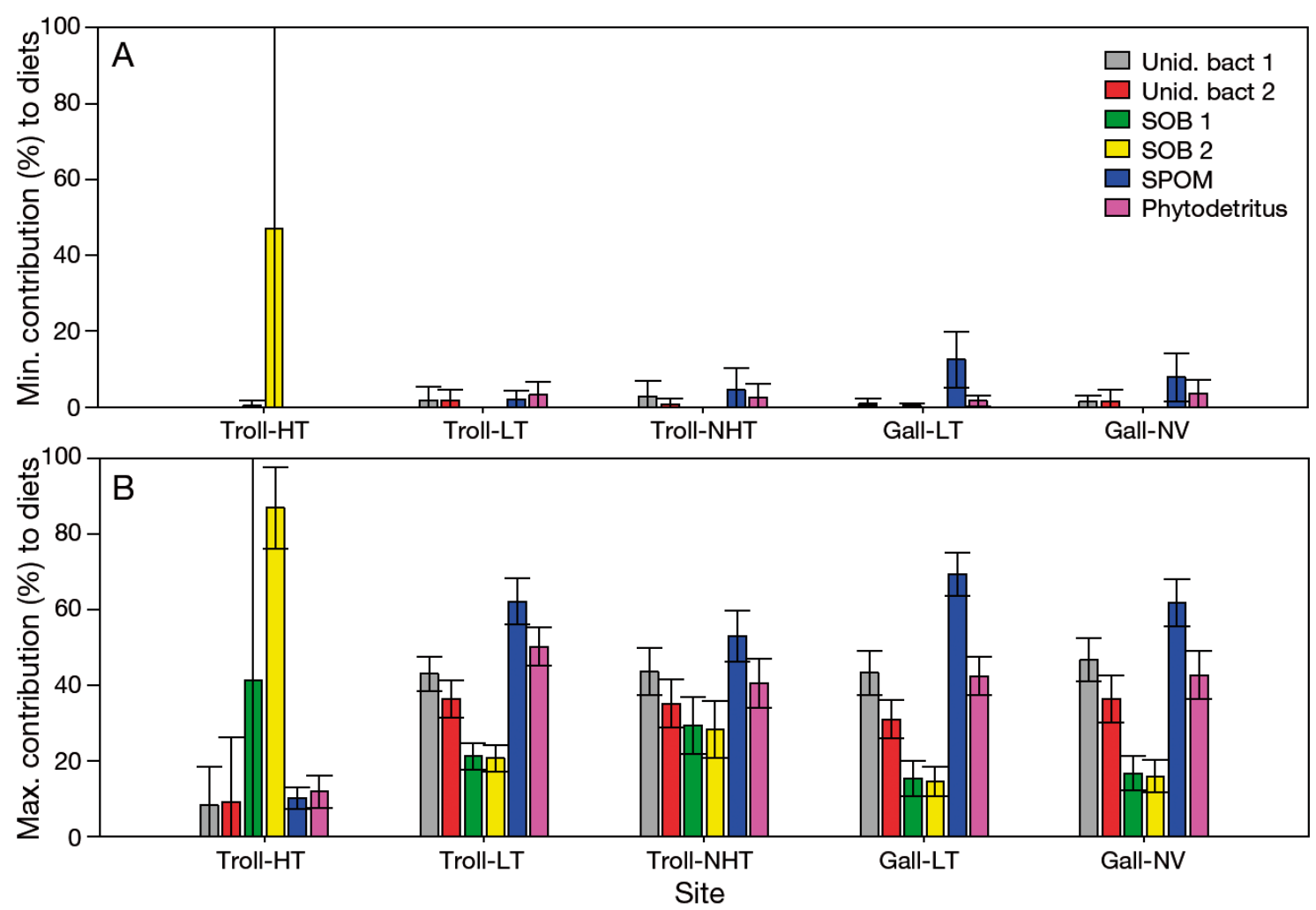

Fig. 7. Mean (A) minimum and (B) maximum percent contribution of specific food sources: Unidentified bacteria (unid. bact) 1 and 2, sulfide oxidizing bacteria (SOB) 1 and 2, phytodetritus, and suspended particulate organic matter (SPOM) to faunal diets at the 5 sites sampled at Trollveggen (Troll) and Gallionella Garden (Gall), at the southern Mohn's Ridge. HT: high temperature vent; LT: low temperature vent; NHT: near HT vent; NV: non-vent. Error bars: $\pm 95 \%$ CI 
subset of animals at each site (Table S2). At the TrollLT site, these taxa included a Skenea basistriata gastropod (max.: 54\%) and an unidentified polychaete (max.: $57 \%$ ). At the Troll-NHT site, SOB was the largest food source for 2 Polycirrus medusa polychaetes (max.: 68\%), an Amphitritinae polychaete (max.: 55\%), an isopod (max.: $57 \%$ ), and a tanaid (max.: $50 \%$ ). SOB contributed a maximum of $84 \%$ to an isopod's diet, and $50 \%$ to a thyasirid bivalve's diet at the Gall-LT site, whilst an ophiuroid derived up to $69 \%$ of its diet from SOB production at the Gall-NV site (Table S2).

\section{DISCUSSION}

The finding of depleted isotopic signatures in Pseudosetia griegi at the Troll-HT site, plus the significantly greater contribution from SOB 2 to their diets compared to the other sites, indicates that chemosynthesis-based food sources can provide a major source of nutrients to one species at HT vent habitats on the SMR. However, we found and collected only 3 specimens from a single microhabitat and studied only one Troll-HT vent. Thus, we cannot rule out the possibility that this and other species at HT sites on the SMR derive energy from photosynthetic food sources. Previous studies showed microhabitat differences in food-web structure on centimeter scales at hydrothermal vents on the Axial Volcano, Juan de Fuca Ridge, where fauna around a high-flow vent opening derived almost $100 \%$ of their diet from chemoautotrophic bacteria, whereas POM contributed $\sim 70 \%$ to faunal diets $70 \mathrm{~cm}$ away in a low flow area (Limén et al. 2007).

While the majority of the fauna we collected appeared to derive a large part of their nutrition from photosynthetic production (Fig. 7), some fauna (16 and $9 \%$ of fauna sampled for isotopes at the Troll LT and Gall-LT sites, respectively) possessed light $\delta^{13} \mathrm{C}$ and light, yet predominantly positive $\delta^{15} \mathrm{~N}$ isotopic signatures, suggesting heterotrophic assimilation of chemosynthetic production (Fig. 5B,D, Table S1). SOB also contributed $\geq 50 \%$ to the diets of some isotopically light fauna here, which included members of the Isopoda, Bivalvia, and Polychaeta (Table S2). The results from this isotopic study are thus in agreement with studies showing wide-ranging differences in primary food sources and trophic structure at vents on the Juan de Fuca Ridge (e.g. Limén et al. 2007) and the MAR (Vereshchaka et al. 2000, De Busserolles et al. 2009). Furthermore, large ranges in $\delta^{13} \mathrm{C}$ signatures were detected between different faunal types at these sites as well as within similar taxa from a single box-core or ROV sample. Thus, microhabitat differences in primary food sources or diet partitioning by species over centimeter scales can exist at hydrothermal vents on the SMR. This extreme patchiness in trophic structure may result from the location of the vents at upper-bathyal depths and the sedimentary environment around the vents, which collectively enhance food availability and diversity (Levin et al. 2009, Soto 2009).

On average, $\delta^{13} \mathrm{C}$ signatures of fauna at the TrollLT, Troll-NHT, Gall-LT and Gall-NV sites were similar to surface-derived SPOM and phytodetritus isotopic signatures. Mean faunal $\delta^{15} \mathrm{~N}$ values were also $\sim 2$ to $4 \%$ heavier than some SPOM signatures. These isotope data collectively suggest that multiple taxa at these sites derive nutrition from photosynthetic production. Mixing model outputs were consistent with these results. The midsummer period in the Norwegian Sea is highly productive and videos taken by the ROV revealed a large abundance of flocculent material throughout the water column including massive bow-shaped strings, possibly aggregated radiolarian phytodetritus (L. A. Levin pers. obs.). High fluxes of labile detritus sinking to the relatively shallow seafloor studied here may contribute to the lack of vent endemism among the benthic fauna (Schander et al. 2010), as well as to the reliance of invertebrates on photosynthetic production at the Troll-LT, TrollNHT, Gall-LT, and Gall-NV sites. The large contribution of photosynthetic production to faunal diets at the 2 LT vents is consistent with studies conducted at shallow seeps in the North Sea (Dando et al. 1991), the California shelf and slope (Levin et al. 2000), as well as at bathyal depth vents on the MAR (De Busserolles et al. 2009) and the Manus Basin (Levin et al. 2009). Reproduction in the endosymbiotic Atlantic vent mussel Bathymodiolus azoricus from the Menez Gwen vent site (840 to $850 \mathrm{~m}$ depth) correlated with the seasonal phytoplankton peak, further pointing to the importance of photosynthetic material to bathyal-depth vent fauna (Dixon et al. 2006).

The high contribution of photosynthetic material at the $2 \mathrm{LT}$ sites is surprising, however, given the ready availability of sulfide and chemosynthetic-based food sources (e.g. SOB) to benthic fauna at these sites (Pedersen et al. 2010a, Schander et al. 2010, Lanzén et al. 2011). One potential explanation for this observation may be that sulfidic conditions where extensive microbial mats occur exclude the abundant nonvent endemic species. This exclusion was shown previously at cold seeps (Barry \& Kochevar 1998, Levin 2005) and hydrothermal vents (Sarrazin et al. 
1999). However, we must emphasize that although $C$ and $\mathrm{N}$ isotopic compositions suggest a predominantly photosynthesis-based food web at the SMR LT habitats, we made no $\delta^{34} \mathrm{~S}$ measurements on any fauna. Thus, nutrition derived from in-situ or exported chemosynthetic production cannot be completely ruled out (Erickson et al. 2009).

Although $\mathrm{C}$ and $\mathrm{N}$ isotopic data revealed that hydrothermal fluids exiting from vents at the 2 LT sites do not appear to greatly influence faunal diets, the vent fluids may contribute indirectly to production through the release of soluble iron into the water column (Thorseth et al. 2007, Yücel et al. 2011), and subsequent enhancement of primary production in the euphotic zone over the vents. At the relatively shallow depths of the Mohn's Ridge system studied here, we hypothesize that the relatively high nutrient concentrations in surface waters typically found around the SMR (compared to more oligotrophic regions) may combine with unbound iron, enhancing photosynthetic production above the vents and elevating fluxes of organic material to the seafloor with subsequent incorporation into vent food webs. While further studies are needed in areas characterized by high as well as low nutrient levels (e.g. vents in the eutrophic North Atlantic versus the oligotrophic Mediterranean) before this hypothesis can be confirmed, circumstantial evidence for elevated iron concentrations and enhanced fluxes of photosynthetic material is apparent at the SMR. For example, vast amounts of siliceous Fe-deposits exist around HT venting areas at the SMR pointing to high iron concentrations in the water column (Thorseth et al. 2007). Moreover, large aggregations of mobile echinoderms (Schander et al. 2010) and zooplankton swarms composed of copepods (Calanus finmarchicus), chaetognaths and anemones (Metridia sp.) have been documented (Aarbakke 2007), suggesting elevated food levels around the vents.

Abundant iron concentrations in the water column, as well as phase separation dynamics (i.e. water boiling at low pressures), may also be a root-cause for the apparent absence of endo- or exosymbiotic incorporation of chemosynthetic production (inferred from the positive $\delta^{15} \mathrm{~N}$ isotopic signatures) at the 2 LT sites, resulting in a fauna largely reliant on other food sources (e.g. photosynthetic material). Soluble iron in the water column may bind much of the free sulfide, and/or phase separation may limit sulfide availability to symbiotic organisms, as shown at the Menez Gwen vent site at $840 \mathrm{~m}$ (Charlou et al. 2000).

\section{Feeding ecology of specific taxa}

The light $\delta^{13} \mathrm{C}$ and $\delta^{15} \mathrm{~N}$ values measured for Pseudosetia griegi from the Troll-HT site, plus the mixing model outputs and the very depleted $\delta^{13} \mathrm{C}$ values for SOB collected at the same location as the gastropods, suggest that $P$. griegi relied on SOB production for a large part of their diet at the Troll-HT site. Thick filamentous mats of SOB (including Sulfurimonas and Sulfurovum) have been documented at HT vent sites at Trollveggen (Schander et al. 2010, Lanzén et al. 2011, see Fig. 2A,B) and Schander et al. (2010) noted that rissoid gastropods occurred in high densities on bacterial mats covering vent chimneys. Positive $\delta^{15} \mathrm{~N}$ values can occur in known symbiontbearing fauna (Fisher et al. 1994, Levin \& Michener 2002, Bergquist et al. 2007, Erickson et al. 2009), but animals that solely rely on endosymbiosis often possess negative or very low (i.e. 0 to $1 \%$ ) $\delta^{15} \mathrm{~N}$ values through fixation of local $\mathrm{N}$ (Conway et al. 1994). The light, but positive $\delta^{15} \mathrm{~N}$ values of $P$. griegi lead us to hypothesize that they graze heterotrophically on the abundant SOB mats present at the Troll-HT site (Lanzén et al. 2011). Grazing on microbial mats was implicated as the main feeding mode for vent gastropods on the Juan de Fuca Ridge (Bergquist et al. 2007), and may be the main feeding mode for several polychaetes and crustaceans at the Troll-LT, TrollNHT, and Gall-LT sites that possessed very light $\delta^{13} \mathrm{C}$ and/or $\delta^{15} \mathrm{~N}$ values.

Although the Pseudosetia griegi $\delta^{13} \mathrm{C}$ signatures at the Troll-LT site were $1 \%$ heavier than mean signatures for SPOM (Figs. 4 \& 5B), the gastropod's light $\delta^{15} \mathrm{~N}$ signatures suggest it is unlikely that they were feeding on recently settled SPOM or phytodetritus. Instead, the lightest $\delta^{15} \mathrm{~N}$ animals from the Troll-LT and Troll-NHT sites were likely feeding on a form of unidentified bacteria. $\delta^{13} \mathrm{C}$-heavy SOB have been detected in reducing habitats in the Gulf of Mexico (Zhang et al. 2002), meaning that the unidentified bacteria sampled in this study could be $\delta^{13} \mathrm{C}$-heavy thiotrophic bacteria. The $P$. griegi animals at Troll-LT and the Troll-NHT sites could also be feeding on $\delta^{13} \mathrm{C}$-heavy methanotrophic bacteria, as found at MAR vents by Trask \& Van Dover (1999) and Colaco et al. (2002b). Microbial community analysis revealed that Gammaproteobacteria contribute up to $10 \%$ of the bacteria in Trollveggen vent sediments, and the majority of these bacteria are from the Methylcoccales order. Thus, methane oxidizers may contribute to the diets of $P$. griegi at a number of vent/near vent locations at the SMR (Lanzén et al. 2011). 
As with the Pseudosetia griegi isotopic signatures, the wide range in $\delta^{13} \mathrm{C}$ signatures for capitellid polychaetes, Polycirrus medusa polychaetes, and amphipods indicates highly generalized diets or food sources with spatially varying signatures. These results thus concur with other vent studies in which wide intra-taxon ranges in isotopic signatures have been found (Limén et al. 2007, De Busserolles et al. 2009). Capitellid polychaetes at both the Troll-LT and -NHT sites comprised some of the isotopically heaviest taxa found. None of the food sources sampled could impart the $\delta^{13} \mathrm{C}$ signatures in 9 out of the 11 heaviest capitellid polychaetes (8 of which were collected from the same scoop during ROV dive 8B-43ROV9 at the Troll-LT site). An exception to this trend was a single capitellid from the Troll-NHT site and another from a box-core sample from the Troll-LT site, which, after correcting for fractionation, possessed $\delta^{13} \mathrm{C}$ signatures of -19.8 and $-20.7 \%$, respectively. While these signatures were almost identical to some unidentified bacterial samples from the Soria Moria vent field, the worms had much heavier $\delta^{15} \mathrm{~N}$ signatures compared to the 2 heaviest unidentified bacteria samples at Soira Moira (Fig. 4, Table S1). Therefore, it appears as though none of the food sources sampled was the primary food source for $\delta^{13} \mathrm{C}$-heavy capitellids at the Troll-LT and -NHT sites.

Interestingly, after correcting for fractionation, the 2 isotopically lightest capitellids found at the TrollNHT had similar isotopic values to signatures for some SPOM samples and the $\delta^{13} \mathrm{C}$ signature of phytoplankton (Figs. 4 \& 5C), suggesting a possible dependency on photosynthetic material. These results, plus the significantly heavier capitellids (in terms of $\delta^{13} \mathrm{C}$ ) at the Troll-LT versus the Troll-NHT site provide evidence for microhabitat differences in capitellid diet both within and between the Trollveggen sites. The ${ }^{13} \mathrm{C}$-enriched capitellids could reflect dependency on microbes using a reverse TCA cycle C-fixation pathway as hypothesized by Levin et al. (2009) and Hügler \& Sievert (2011). Consumption of $\delta^{13} \mathrm{C}$-heavy methanotrophic microbes (Trask \& Van Dover 1999, Colaco et al. 2002b, Lanzén et al. 2011) could also impart comparatively heavy $\delta^{13} \mathrm{C}$ signatures in some of the sampled capitellids. However, while a variety of food sources could lead to comparatively different $\delta^{13} \mathrm{C}$ signatures in the capitellids at the Troll-LT and -NHT sites, they may all feed from a similar, but isotopically variable food source. Further studies using both stable isotope and fatty acid analysis are needed to resolve the capitellid food sources.

The light $\delta^{15} \mathrm{~N}$ values measured for Polycirrus medusa at the Troll-NHT site, plus the significantly lighter $\delta^{13} \mathrm{C}$ signatures in polychaetes at this site compared to the Gall-NV site, suggests consumption of material of a chemosynthetic origin (e.g. SOB) at the Troll-NHT site. At the Gall-LT, Gall-NV and Troll-LT sites, the polychaetes display dual isotopic signatures indicative of ingestion of photosynthetically derived $\mathrm{C}$ and $\mathrm{N}$ with light $\delta^{15} \mathrm{~N}$ values, though grazing on bacteria may also be a possibility. These results are in agreement with vent studies from the Guaymas Basin, Gulf of California, where wide ranging $\delta^{13} \mathrm{C}$ signatures were measured in the ampharetid polychaete Amphisamytha galapagensis (Soto 2009), highlighting its role as a trophic generalist. Trophic generalism has also been suggested for other polychaete species (e.g. the maldanid polychaete Nicomache [Loxochona] lokii) from the Loki's Castle vent field (Kongsrud \& Rapp 2012).

The close agreement between some phytodetritus, SPOM, and the amphipod $\delta^{13} \mathrm{C}$ signatures at the Gall-LT, Troll-LT and Troll-NHT sites, plus the $\sim 3 \%$ heavier $\delta^{15} \mathrm{~N}$ values in some amphipods relative to phytoplankton derived material and SPOM samples (Figs. 4 \& 5B-D, Table S1), suggest that the amphipods were feeding on SPOM and/or phytodetritus with light $\delta^{15} \mathrm{~N}$ signatures. Mixing model results support this hypothesis (e.g. some amphipods derived up to 68 and $84 \%$ of their energy requirements from phytodetritus and SPOM, respectively).

\section{General trophic structure of the fauna studied}

Faunal $\delta^{15} \mathrm{~N}$ values at the Troll-LT, Troll-NHT, Gall-LT and Gall-NV sites indicated multiple trophic levels at each site (providing a 3\% trophic enrichment factor; Minagawa \& Wada 1984). Assuming SPOM was the primary food source at these sites and taking $4.5 \%$ as a minimum $\delta^{15} \mathrm{~N}$ value for SPOM (Fig. 4), and a $3 \%$ trophic enrichment factor (Minagawa \& Wada 1984), it is possible to predict the degree of trophic-level complexity at each site (i.e. minimum number of trophic levels). Based on the highest faunal $\delta^{15} \mathrm{~N}$ values at the $2 \mathrm{LT}$ vent locations, the Troll-LT and Gall-LT sites support $\sim 2$ and 3 trophic levels, respectively. The Troll-NHT habitat supports $\sim 2$ trophic levels compared with 3 at the Gall-NV site (Table S1). Because Pseudosetia griegi occupies the first trophic level at the Troll-HT site, our results are consistent with studies that show a large degree of diversity in food-web structure at hydrothermal vents such as those on the Marianas Back Arc Spreading Centre (Van Dover \& Fry 1989), 
the Gorda Ridge (Van Dover \& Fry 1994), and the MAR (Colaco et al. 2002a), and in hydrothermal sediments at Middle Valley (Levin et al. 2009).

\section{Export of chemosynthetic production}

Export of chemosynthetic production out of vent habitats, and transport of vent-derived particulate organic material over $\mathrm{km}$ scales has been documented previously by Dymond \& Roth (1988). In this study, isotopically light $\delta^{13} \mathrm{C}$ and $\delta^{15} \mathrm{~N}$ signatures occurred in an ophiuroid at the Gall-NV site, which our mixing model analysis attributed largely to known chemosynthetic production. It is unlikely that the isotopically light ophiuroid assimilated chemosynthetic production from one of the vent sites ( $\sim 2 \mathrm{~km}$ away) and then migrated to the Gall-NV site because the ophiuroid was very small. Instead, chemosynthetic production was likely transported from one of the studied vent sites to the Gall-NV site where it was assimilated, or material was transported from a much closer, but undiscovered vent habitat. In light of only a single animal with light $\delta^{13} \mathrm{C}$ signatures at the Gall-NV site, we suggest that fauna at the Gall-NV site do not heavily rely on chemosynthetic production. However, we recommend further studies at the SMR test for the export of chemosynthetic production from vent to non-vent habitats.

\section{SUMMARY}

This study of trophic structure at vent sites on the SMR revealed spatial differences in trophic structure between HT and LT vent habitats. Despite dominance by background (non-vent) taxa at the vent habitats, and the absence of chemosymbiont-bearing fauna, multiple taxa apparently rely on heterotrophic consumption of chemosynthetic production for energy. These results also highlight the need for rigorously designed sampling programs that integrate processes at multiple spatial scales in order to obtain a more complete understanding of food-web structure at deep-sea vent habitats in the Arctic Ocean.

Acknowledgements. We (A.K.S., L.A.L. and H.T.R.) dedicate this paper to our close friend, collaborator and coauthor, Prof. Christoffer Schander, who passed away unexpectedly and far too soon in February 2012. Christoffer inspired the work presented here, and was an inspiration to those that knew him. The fields of marine biology and deep-sea biology have been forever advanced by his significant contributions. We thank the Bergen forskningsstiftelse for funding to
C.S. to support this research. We thank A. Gebruk for helping sample, sort, and identify specimens at sea, the captain and crew of the RV 'G. O. Sars' for their assistance and chief scientist R.-B. Pedersen for his assistance in the field. The pilots of the ROV 'Bathysaurus' are thanked for excellent assistance in collecting the samples. We also thank J. Gonzalez (Scripps Inst. Oceanography) for assistance with preparing isotope samples and R. Lee (Washington State University) for providing stable isotope analyses. The Centre of Excellence in Geobiology at the University of Bergen is thanked for allowing L.A.L. to participate in the cruise BIODEEP. T. Bakken, J. Berge, S. Cochrane, Ø. Fjukmoen, T. Høisæter, J. A. Kongsrud, K. Lundin, E. Oug, P. Schuchert, S. Støhr and A. Warén are thanked for aiding with species identifications. Finally, we thank P. Dando, P. Snelgrove and 2 anonymous reviewers who provided suggestions that greatly improved our manuscript.

\section{LITERATURE CITED}

Aarbakke ONS (2007) Bio-acoustic investigations of the sound scattering layers overlaying hydrothermal vents in the Arctic Ocean. MSc thesis, University of Bergen

Barry JP, Kochevar RE (1998) A tale of two clams: differing chemosynthetic life styles among vesicomyids in Monterey Bay cold seeps. Cah Biol Mar 39:329-331

Bergquist DC, Eckner JT, Urcuyo IA, Cordes EE, Hourdez S, Macko SA, Fisher CR (2007) Using stable isotopes and quantitative community characteristics to determine a local hydrothermal vent food web. Mar Ecol Prog Ser 330:49-65

> Bernardino A, Smith CR (2010) Community structure of infaunal macrobenthos around vestimentiferan thickets at the San Clemente cold seep, NE Pacific. Mar Ecol 31: 608-621

> Charlou JL, Donval JP, Douville E, Jean-Baptiste P and others (2000) Compared geochemical signatures and the evolution of Menez Gwen $\left(37^{\circ} 50^{\prime} \mathrm{N}\right)$ and Lucky Strike $\left(37^{\circ} 17^{\prime} \mathrm{N}\right)$ hydrothermal fluids, south of the Azores Triple Junction on the Mid-Atlantic Ridge. Chem Geol 171: 49-75

> Colaco A, Dehairs F, Desbruyères D (2002a) Nutritional relations of deep-sea hydrothermal fields at the Mid-Atlantic Ridge: a stable isotope approach. Deep-Sea Res I 49: 395-412

Colaco A, Dehairs F, Desbruyères D, Le Bris N, Sarradin PM (2002b) $\delta^{13} \mathrm{C}$-signature of hydrothermal mussels is related with the end-member fluid concentrations of $\mathrm{H}_{2} \mathrm{~S}$ and $\mathrm{CH}_{4}$ at the Mid-Atlantic Ridge hydrothermal vent fields. Cah Biol Mar 43:259-262

Conway N, Kennicutt M, Van Dover C (1994) Stable isotopes in the study of marine chemosynthetic based ecosystems In: Lajtha K, Michener R (eds) Stable isotopes in ecology and environmental sciences. Blackwell Scientific Publications, London, p 158-186

> Dando PR, Austen MC, Burke RA, Kendall MA and others (1991) Ecology of a North Sea pockmark with an active methane seep. Mar Ecol Prog Ser 70:49-63

> De Busserolles F, Sarrazin J, Gauthier O, Gélinas Y, Fabri MC, Sarradin PM, Desbruyères D (2009) Are spatial variations in the diets of hydrothermal fauna linked to local environmental conditions? Deep-Sea Res II 56: 1649-1664

> Demopoulos AWJ, Gualtieri D, Kovacs K (2010) Food-web 
structure of seep sediment macrobenthos from the Gulf of Mexico. Deep-Sea Res II 57:1972-1981

Desbruyères D, Biscoito M, Caprais JC, Colaco A and others (2001) Variations in deep-sea hydrothermal vent communities on the Mid-Atlantic Ridge near the Azores plateau. Deep-Sea Res I 48:1325-1346

> Dixon DR, Lowe DM, Miller PI, Villemin GR, Colao A, Serrão-Santos R, Dixon LRJ (2006) Evidence of seasonal reproduction in the Atlantic vent mussel Bathymodiolus azoricus, and an apparent link with the timing of photosynthetic primary production. J Mar Biol Assoc UK 86: 1363-1371

> Dubilier N, Bergin C, Lott C (2008) Symbiotic diversity in marine animals: the art of harnessing chemosynthesis. Nat Rev Microbiol 6:725-740

> Dymond J, Roth S (1988) Plume dispersed hydrothermal particles: a time-series record of settling flux from the Endeavour Ridge using moored sensors. Geochim Cosmochim Acta 52:2525-2536

> Erickson KL, Macko SA, Van Dover CL (2009) Evidence for a chemoautotrophically based food web at inactive hydrothermal vents (Manus Basin). Deep-Sea Res II 56: 1577-1585

Fisher CR, Childress JJ, Macko SA, Brooks JM (1994) Nutritional interactions at Galapagos hydrothermal vents: inferences from stable carbon and nitrogen isotopes. Mar Ecol Prog Ser 103:45-55

Fry B, Sherr EB (1984) $\delta^{13} \mathrm{C}$ measurements as indicators of carbon flow in marine and freshwater ecosystems. Contrib Mar Sci 27:13-47

> Gaudron SM, Lefebvre S, Nunes Jorge A, Gaill F, Pradillon F (2012) Spatial and temporal variations in food web structure from newly-opened habitat at hydrothermal vents. Mar Environ Res 77:129-140

> Hügler M, Sievert SM (2011) Beyond the Calvin cycle: autotrophic carbon fixation in the ocean. Ann Rev Mar Sci 3:261-289

Kennicutt MC II, Burke RA Jr, MacDonald IR, Brooks JM, Denoux GJ, Macko SA (1992) Stable isotope partitioning in seep and vent organisms: chemical and ecological significance. Chem Geol 101:293-310

> Kongsrud JA, Rapp HT (2012) Nicomache (Loxochona) lokii sp. nov. (Annelida, Polychaeta, Maldanidae) from the Loki's Castle vent field: an important structure builder in an Arctic vent system. Polar Biol 35:161-170

> Lanzén A, Jørgensen SL, Bengtsson MM, Jonassen I, Øvreås L, Urich T (2011) Exploring the composition and diversity of microbial communities at the Jan Mayen hydrothermal vent field using RNA and DNA. FEMS Microbiol Ecol 77:577-589

> Levin LA (2005) Ecology of cold seep sediments: interactions of fauna with flow, chemistry, and microbes. Oceanogr Mar Biol Annu Rev 43:1-46

> Levin LA, Mendoza GF (2007) Community structure and nutrition of deep methane-seep macrobenthos from the North Pacific (Aleutian) margin and the Gulf of Mexico (Florida Escarpment). Mar Ecol 28:131-151

> Levin LA, Michener R (2002) Isotopic evidence of chemosynthesis-based nutrition of macrobenthos: the lightness of being at Pacific methane seeps. Limnol Oceanogr 47: 1336-1345

Levin LA, James DW, Martin CM, Rathburn A, Harris L, Michener R (2000) Do methane seeps support distinct infaunal assemblages? Observations on community structure and nutrition from the northern California slope and shelf. Mar Ecol Prog Ser 208:21-39

> Levin LA, Mendoza GF, Konotchick T, Lee R (2009) Community structure and trophic relationships in Pacific hydrothermal sediments. Deep-Sea Res II 56:1632-1648

> Limén H, Levesque C, Kim Juniper S (2007) POM in macro/meiofaunal food webs associated with three flow regimes at deep-sea hydrothermal vents on Axial Volcano, Juan de Fuca Ridge. Mar Biol 153:129-139

Lizarralde D, Adam Soule S, Seewald JS, Proskurowski G (2011) Carbon release by off-axis magmatism in a young sedimented spreading centre. Nature Geosci 4:50-54

Minagawa M, Wada E (1984) Stepwise enrichment of ${ }^{15} \mathrm{~N}$ along food chains: further evidence and the relation between $\delta^{15} \mathrm{~N}$ and animal age. Geochim Cosmochim Acta 48:1135-1140

Ohara Y, Reagan MK, Fujikura K, Watanabe H and others (2012) A serpentinite-hosted ecosystem in the Southern Mariana Forearc. Proc Natl Acad Sci USA 109: 2831-2835

Paull CK, Jull AJT, Toolin LJ, Linick T (1985) Stable isotope evidence for chemosynthesis in an abyssal seep community. Nature 317:709-711

Pedersen RB, Thorseth IH, Hellevang B, Schultz A, Taylor P, Knudsen HP, Steinsbu BO (2005) Two vent fields discovered at the ultraslow spreading Arctic ridge system. Eos Trans Am Geophys Union 86(52):OS21C-01

Pedersen RB, Thorseth IH, Nygård TE, Lilley M, Kelley D (2010a) Hydrothermal activity at the Arctic Mid-Ocean Ridge. In: Rona PA, Devey CW, Dyment J, Murton BJ (eds) Diversity of hydrothermal systems on slow spreading ocean ridges. Geophys Monogr Ser 188, American Geophysical Union, Washington, DC, p 67-89

> Pedersen RB, Rapp HT, Thorseth IH, Lilley M and others (2010b) Discovery of a black smoker field and a novel vent fauna at the ultraslow spreading Arctic Mid-Ocean Ridges. Nat Comm 1:126

> Phillips DL, Gregg JW (2003) Source partitioning using stable isotopes: coping with too many sources. Oecologia 136:261-269

> Rau GH (1981) Low ${ }^{15} \mathrm{~N} /{ }^{14} \mathrm{~N}$ in hydrothermal vent animals: ecological implications. Nature 289:484-485

Rau GH, Hedges JI (1979) Carbon-13 depletion in a hydrothermal vent mussel: suggestion of a synthetic food source. Science 203:648-649

> Sarrazin J, Kim Juniper S, Massoth G, Legendre P (1999) Physical and chemical factors influencing species distributions on hydrothermal sulfide edifices of the Juan de Fuca Ridge, northeast Pacific. Mar Ecol Prog Ser 190: 89-112

> Schander C, Rapp HT, Kongsrud JA, Bakken T and others (2010) The fauna of hydrothermal vents on the Mohn Ridge (North Atlantic). Mar Biol Res 6:155-171

> Smith CR, De Leo FC, Bernardino AF, Sweetman AK, Martinez Arbizu P (2008) Abyssal food limitation, ecosystem structure and climate change. Trends Ecol Evol 23:518-528

> Smith KL, Ruhl HA, Bett BJ, Billett DSM, Lampitt RS, Kaufmann RS (2009) Climate, carbon cycling and deep-ocean ecosystems. Proc Natl Acad Sci USA 106:19211-19218

Soto LA (2009) Stable carbon and nitrogen isotopic signatures of fauna associated with the deep-sea hydrothermal vent system of Guaymas Basin, Gulf of California. Deep-Sea Res II 56:1675-1682

Tandberg AHS, Rapp HT, Schander C, Vader W, Sweetman AK, Berge J (2012) Exitomelita sigynae gen. et sp. nov.: a new amphipod from the Arctic Loki Castle vent field 
with potential gill ectosymbionts. Polar Biol 35:705-716

Tarasov VG, Gebruk AV, Mironov AN, Moskalev LI (2005) Deep-sea and shallow-water hydrothermal vent communities: two different phenomena? Chem Geol 224:5-39

Thorseth IH, Pedersen RB, Kruber C, Kosler J (2007) Lowtemperature hydrothermal deposits at the $71^{\circ} \mathrm{N}$ vent fields at the Arctic Mid-Ocean Ridge: architecture, microtextures, and geochemistry. Eos Trans Am Geophys Union 88(52):OS43A-0996 (abstract)

Thurber AR, Kröger K, Neira C, Wiklund H, Levin LA (2010) Stable isotope signatures and methane use by New Zealand cold seep benthos. Mar Geol 272:260-269

Trask J, Van Dover C (1999) Site-specific and ontogenetic variations in nutrition of mussels (Bathymodiolus sp.) from the Lucky Strike hydrothermal vent field, MidAtlantic Ridge. Limnol Oceanogr 44:334-343

- Utne-Palm AC, Salvanes AGV, Currie B, Kaartvedt S and others (2010) Trophic structure and community stability in an overfished ecosystem. Science 329:333-336

> Van der Bank MG, Utne-Palm AC, Pittman K, Sweetman AK, Richoux NB, Brüchert V, Gibbons MJ (2011) Studies on the integrated feeding of Sufflogobius bibarbatus (von Bonde, 1923) in the Northern Benguela ecosystem using fatty acid biomarkers and stable isotopes. Mar Ecol

Editorial responsibility: Paul Snelgrove, St. John's, Newfoundland and Labrador, Canada
Prog Ser 428:219-233

Van Dover CL (2000) The ecology of deep-sea hydrothermal vents. Princeton University Press, Princeton, NJ

> Van Dover CL, Fry B (1989) Stable isotopic compositions of hydrothermal vent organisms. Mar Biol 102:257-263

Van Dover CL, Fry B (1994) Microorganisms as food resources at deep-sea hydrothermal vents. Limnol Oceanogr 39:51-57

> Vanreusel A, Van den Bossche I, Thiermann F (1997) Freeliving marine nematodes from hydrothermal sediments: similarities with communities from diverse reduced habitats. Mar Ecol Prog Ser 157:207-219

> Vereshchaka AL, Vinogradov GM, Yu. Lein A, Dalton S, Dehairs F (2000) Carbon and nitrogen isotopic composition of the fauna from the Broken Spur hydrothermal vent field. Mar Biol 136:11-17

> Yücel M, Gartman A, Chan CS, Luther GW (2011) Hydrothermal vents as a kinetically stable source of ironsulfide-bearing nanoparticles to the ocean. Nat Geosci 4:367-371

Zhang CL, Li Y, Wall JD, Larsen L and others (2002) Lipid and carbon isotopic evidence of methane-oxidizing and sulfate-reducing bacteria in association with gas hydrates from the Gulf of Mexico. Geology 30:239-242

Submitted: August 30, 2011; Accepted: September 13, 2012 Proofs received from author(s): December 21, 2012 